\title{
AVALIAÇÃO DE DANOS MECÂNICOS EM SEMENTES DE SOJA POR MEIO DA ANÁLISE DE IMAGENS
}

\section{EBERT PEPE OBANDO FLOR}

Tese apresentada à Escola Superior de Agricultura "Luiz de Queiroz", Universidade de São Paulo, para obtenção do título de Doutor em Agronomia, Área de Concentração: Fitotecnia

P I R A C I C A B A

Estado de São Paulo - Brasil

Julho - 2003 


\section{AVALIAÇÃO DE DANOS MECÂNICOS EM SEMENTES DE SOJA POR MEIO DA ANÁLISE DE IMAGENS}

\section{EBERT PEPE OBANDO FLOR}

Engenheiro Agrônomo

Orientador: Prof. Dr. SILVIO MOURE CÍCERO Co-orientador: Dr. JOSÉ DE BARROS FRANÇA NETO

Tese apresentada à Escola Superior de Agricultura "Luiz de Queiroz", Universidade de São Paulo, para obtenção do título de Doutor em Agronomia, Área de Concentração: Fitotecnia

P I R A C I C A B A

Estado de São Paulo - Brasil

Julho - 2003 


\section{Dados Internacionais de Catalogação na Publicação (CIP)}

DIVISÃO DE BIBLIOTECA E DOCUMENTAÇÃO - ESALQ/USP

\section{Flor, Ebert Pepe Obando}

Avaliação de danos mecânic os em sementes de soja pormeio da análise de imagens/ Ebert Pepe Obando Flor.- - Piracicaba, 2003.

72 p. : il.

Tese (doutorado) - Escola Supenior de Agricultura Luiz de Queiroz, 2003. Bibliografia.

1. Dano mecânico 2. Qualidade fisiológica 3. Sementes 4. Soja I. Título

CDD 633.34 
A Dios por estar siempre conmigo......

\section{A mis padres José y Eloida:}

Por que siempre creyeron y me incentivaron, sacrificando sus sueños en favor de los mios.

No fueron apenas padres tambien amigos y compañeros, en las horas difíciles en que mis ideales parecian distantes e inalcanzables.

Gracias a ustedes, por la comprensión cuando me distancié todo este tiempo de la família.

Gracias por el sueño que realizo en este dia y sobretodo, gracias por la lección de amor que me enseñaron durante toda la vida.

Y que durante la lucha del dia a dia, pueda repasar a mis descendientes la misma dignidad con la cual ustedes supieron inculcarme. 
A mis hermanos y sobrino: Moisés, Ana y Phooll

A ustedes, que compartieron mis ideales y los alimentaron, incentivandome a proseguir en esta jomada, sin importar cualquier obstáculo que se presentó, y a pesar de la distancia, permanecieron siempre a mi lado, dedico mi victória con el mas profundo agradecimiento y respeto.

\section{À minha esposa Luciana:}

Compañera de todas las horas, que con mucho amor y comprensión supo enfrentar a mi lado todos los desafios de este trabajo. 


\title{
AGRADECIMENTOS
}

\begin{abstract}
À Universidade de São Paulo - Escola Superior de Agricultura "Luiz de Queiroz" - (ESALQ-USP), através do Departamento de Produção Vegetal, pela oportunidade da realização do Curso de D outorado.

Ao professor Dr. Silvio Moure Cícero pelas orientações irrestritas, incentivos, apoio incondicional, amizade, paciência e conhecimentos transmitidos e também pelo exemplo profissional como pessoa, educador e pesquisador, minha profunda admiração e gratidão.
\end{abstract}

Ao Co-orientador, Dr. José de Barros França Neto pela coorientação, amizade, pela especial atenção, incentivo e conselhos dedicados.

Ao Dr. Francisco Carlos Krzyzanowski, pela orientação, companheirismo e pela atenção nas minhas viagens a Londrina.

Aos professores Ana Dionisia da Luz Coelho Novembre, Julio Marcos Filho e Walter Rodrigues da Silva pelas sugestões, amizade e os ensinamentos repassados durante 0 curso.

À Eng. Agr. MSc. Helena M. C. Pescarin Chamma, pelo apoio no Laboratório de Análise de Sementes e pela amizade.

À Elisa Nakamura, do Laboratónio de Sementes da Embrapa Soja, pela atenção, facilidades e pelos ensinamentos no teste do tetrazólio.

A CAPES pela concessão de bolsa de estudos. 
Ao funcionário Hodair Luiz Banzatto Júnior pelo apoio na análise de imagens.

Aos funcionários do Departamento de Produção Vegetal e Laboratório de Análise de Sementes pelo convívio e colaboração na condução da pesquisa, especialmente ao João e Carlão.

A Ilze Helena Neves, pela amizade.

Às secretárias do Programa de Pós-Graduação em Fitotecnia Luciane Lopes e Maria e Ivete Almeida, pela atenção a mim dispensada.

À E liana pela eficiência nas correções bibliográficas.

À Empresa Brasileira de Pesquisa Agropecuária (Embrapa Soja) pelo fornecimento das sementes.

À amiga Roselí pela revisão da tese.

Aos grandes amigos da Pós-Graduação do Laboratório de Análise de Sementes: Cibele, Cristina , Everton, José Luiz, Magali, Nilza Patrícia, O smar, Sâmara, Silvia e Virgínia: ficaram para mim as melhores lembranças de amizade.

Aos meus amigos dos jogos de campo Simão, Magrão, Mineiro, Penha, Neco, Moçú, Ananias, Rodrigo, Tobias: obrigado pela amizade, e obrigado por permitir mostrar a vocês que no Peru também jogamos futebol.

Ao meu grande amigo Eder Jorge de O liveira, pela demonstração de grande amizade e companheirismo durante os anos de convívio.

Aos amigos que conviveram comigo na república: Fernando, Tassiano, Kayo e Frederico.

À comunidade de estrangeiros da ESALQ, em especial aos amigos e conterrâneos peruanos Percy, Manuel, Javier, Edwin, Walter e Juan. 
Ao meu tio Luis Narro, incentivador de todos meus sucessos alcançados.

Ao meu tio Julio Flor, pesquisador e profundo conhecedor das riquezas lingüísticas do Peru.

Aos meus tios Llucu, Maritza, Teodoro, César e minha prima Luchi pelo carinho de sempre.

Aos amigos e pesquisadores Alexander Chavez e Juan Risi pela amizade e oportunidade de acreditar em nosso país.

Aos meus sogros Francisco e Gildete, meus cunhados Rosana, Reginaldo e Luz.

Aos meus amigos Ana, Duda, Guillermo, Juani, Chechi, Dino, Karla, Olenka, Sofia e Collao.

Tantas pessoas passaram em minha vida, cada uma com a sua peculiaridade e história, agradeço a todos que, de uma forma direta ou indireta, contribuíram para o meu crescimento como ser humano e para a realização dessa pesquisa. 


\section{SUMÁRIO}

Página

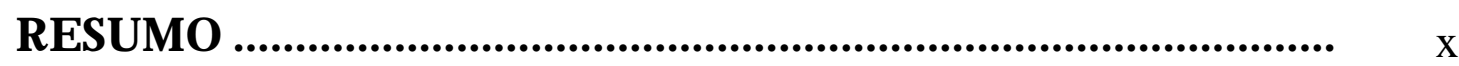

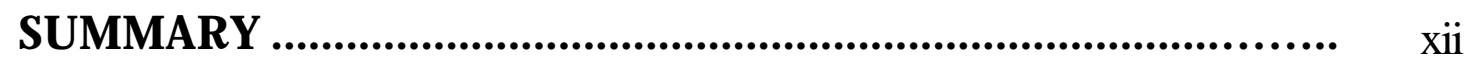

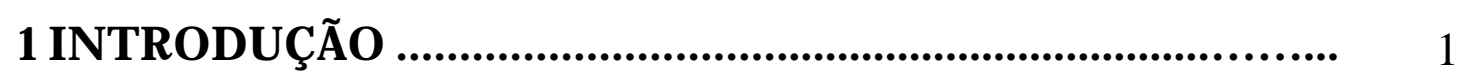

2 REVISÃO DE LITERATURA ................................................... 3

2.10 corrência de D anos Mecânicos...................................................... 3

2.2 Análise de Imagens........................................................................ 6

3 MATERIAL E MÉTODOS......................................................... 11

3.1 Teor de água das sementes............................................................ 13

3.2 Teste de germinação ......................................................................... 13

3.3 Teste de tetrazólio ....................................................................... 13

3.4 T este de envelhecimento acelerado..................................................... 14

3.5 Teste de condutividade elétrica....................................................... 14

3.6 Teste de emergência das plântulas......................................................... 15

3.7 D anificação das sementes através do teste do pêndulo ....................... 15

3.8 Detecção dos danos mecânicos por meio da análise de imagens................................................................................................ 18

3.9 Detecção dos danos mecânicos por meio do teste do tetrazólio........................................................................................ 20

3.10 Análise dos resultados e procedimento estatístico............................ 21

4 RESULTADOS E DISCUSSÃO ................................................ 22

4.1 Avaliação da qualidade inicial das sementes........................................ 22 
4.2 Avaliação de danos mecânicos pela análise de imagens....................... $\quad 25$

4.3 Teste de tetrazólio ........................................................................................ 51

4.4 Considerações gerais ................................................................... 62

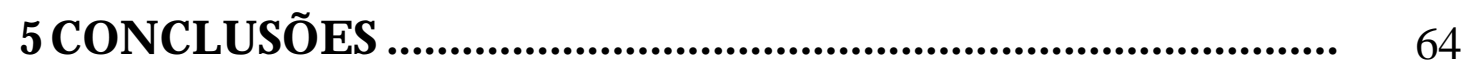

REFERÊNCIAS BIBLIOGRÁFICAS ............................................. 65 


\title{
AVALIAÇÃO DE DANOS MECÂNICOS EM SEMENTES DE SOJA POR MEIO DA ANÁLISE DE IMAGENS
}

\author{
Autor: EBERT PEPE OBANDO FLOR \\ orientador: Prof. Dr. SILVIO MOURE CÍCERO \\ Co-orientador: Dr. JOSÉ DE BARROS FRANÇA NETO
}

\section{RESUMO}

O presente trabalho visou desenvolver um método não convencional para a determinação de danos mecânicos em sementes de soja e sua relação com a qualidade fisiológica, utilizando a técnica de análise de imagens. Como a referida técnica proporciona a análise das sementes sem destruí-las, coisa que acontece nos testes tradicionalmente utilizados, é possível comprovar, por meio do teste de germinação, quais danos detectados pela análise de imagens são realmente importantes, em função dos prejuízos causados ao processo germinativo. A pesquisa foi conduzida com três cultivares de soja (FT-2, FT-10 e IAC-2), cujas sementes apresentam diferentes teores de lignina no tegumento (diferentes comportamentos quanto à resistência aos danos mecânicos). Os danos mecânicos foram provocados por meio do teste do pêndulo em seis diferentes regiões das sementes. A detecção dos danos mecânicos foi feita por 
meio da análise de imagens e por meio do teste do tetrazólio. Os resultados obtidos indicaram que a análise de imagens permite identificar danos mecânicos externos e internos em sementes de soja; também, permitiu observar danos por umidade e danos por percevejo, correlacionando-se positivamente com o teste de tetrazólio, nas avaliações de danos mecânicos e de viabilidade das sementes. 


\title{
EVALUATION OF MECHANICAL DAMAGES IN SOYBEAN SEEDS BY IMAGE ANALYSIS
}

\author{
Author: EBERT PEPE OBANDO FLOR \\ Adviser. Prof. Dr. SILVIO MOURE CICERO \\ Co-adviser: Dr. JOSÉ DE BARROS FRANÇA NETO
}

\section{SUMMARY}

The present work had the objective of developing a non-conventional method for determination of mechanical damage in soybean seeds, and also to verify its relation to the physiological quality, using the technique of image analysis. Unlike to the traditional tests, this technique provides the analysis of seeds without destroying them, and together with germination test, it can be observed that the damages detected in the image analysis is really important because of their influence in the germinative process. The research was carried out with three cultivars of soybean (FT-2, FT-10 and IAC-2), possessing different contents of lignin in the seed coat (different behaviors to the resistance for mechanical damages). The mechanical damages had been caused by means of the pendulum test in six different regions of the seeds. The detection of the mechanical damages was made by means of image analysis and by means of tetrazolium test. The image analysis identified external and internal mechanical 
damages in soybean seeds, and also, was efficient to detect weathering and stinkbug damages. The image analysis presented a positive correlation will the tetrazolium test when it was considered the evaluation of the mechanical damage and the viability of the seeds. 


\section{INTRODUÇÃO}

Com a globalização da economia estão ocorrendo profundas mudanças na agricultura e muitas destas mudanças estão também ocorrendo nas empresas produtoras de sementes, as quais estão cientes de que os produtores estão mais exigentes e, por isso, está havendo a necessidade de tornarem-se altamente competitivas e eficientes.

Por essa razão, as empresas de sementes estão investindo em programas de melhoramento genético, que tem resultado no lançamento de uma grande quantidade de materiais com características desejadas no mercado. Assim, a semente está deixando de ser um insumo barato e passando a ter um custo mais elevado, devido à agregação de valores, transformando-se no principal veículo de transferência das novas tecnologias para 0 agricultor 0 qual, por estar pagando preços maiores, exige alta qualidade das sementes adquiridas.

Entre as causas responsáveis pela perda da qualidade em sementes de soja, destacam-se os danos mecânicos provocados, principalmente, durante as operações de colheita e beneficiamento. Trincas ou rachaduras situadas superficialmente são facilmente detectadas, ao passo que os danos mecânicos internos exigem exames mais detalhados para sua detecção. Vale ressaltar que não apenas os danos grandes e visíveis, mas também danos menores ou microdanos, mesmo que invisíveis a olho nu, dependendo da sua localização, podem reduzir significativamente a qualidade das sementes. 
A utilização de técnicas que sejam rápidas e precisas na identificação de injúrias mecânicas em sementes, como o tetrazólio e a análise de imagens, se traduzem em ferramentas de grande importância em programas de controle de qualidade de sementes.

Diante do exposto, este trabalho foi realizado com o intuito de avaliar a eficiência da utilização da técnica de análise de imagens na identificação dos danos mecânicos em sementes de soja e sua relação com a qualidade fisiológica. 


\section{REVISÃO DE LITERATURA}

\subsection{0 comência de Danos Mecânicos}

As sementes de soja quando atingem o estádio de maturidade fisiológica, apresentam grau mais elevado de qualidade; posteriormente, ocorre 0 armazenamento no campo, resultando na gradual, muitas vezes rápida, mas sempre irreversível perda de vigor da semente até a próxima semeadura (França Neto \& Henning, 1984; Kueneman, 1989). As causas da deterioração das sementes podem ser devido, principalmente, às adversidades climáticas no campo, armazenamento em ambientes úmidos e quentes, danos mecânicos durante as operações de colheita, transporte, manuseio e beneficiamento; em certas condições as causas patológicas, fisiológicas ou mecânicas agem sinergisticamente (Kueneman, 1989).

O conceito de dano mecânico é restrito aos distúrbios resultantes das forças destrutivas ocorridas durante a semeadura, colheita, trilha, transporte e beneficiamento. Dentro do processo de produção de sementes, a injúria mecânica é uma das mais importantes causas da redução da qualidade da semente de soja. Estas injúrias não podem ser totalmente evitadas, mas sua extensão e severidade podem ser grandemente atenuadas (Popinigis, 1985). França Neto et al. (1987) verificaram que o dano mecânico durante a colheita foi 
o fator que mais afetou a qualidade das sementes de soja, seguidos pela deterioração por umidade e danos por percevejos.

A semente de soja é muito sensível ao dano mecânico, uma vez que as partes vitais do eixo embrionário (radícula, hipocótilo e plúmula), estão situadas sob um tegumento pouco espesso, que praticamente não lhe oferece proteção (França Neto \& Henning, 1984), sendo, então, a injúria mecânica, causada durante os processos de colheita e beneficiamento das sementes, uma das principais causas da redução da sua qualidade (Popinigis, 1972), podendo levar à condenação dos lotes de sementes.

A conseqüência do impacto mecânico sobre a semente de soja, varia de acordo com a posição de ocorrência do dano. As regiões do eixo embrionário, oposta ao hilo, oposta à região do eixo embrionário, do hilo e do lado da semente foram, respectivamente, as posições que mais influenciaram para queda do vigor das sementes (Barstch et al., 1986).

A susceptibilidade do tegumento da semente ao dano mecânico se constitui em caráter importante para a qualidade de sementes de soja, a qual está intimamente relacionada com a variabilidade genética (Carbonell, 1991).

Estudos mais recentes têm comprovado a relação direta entre a resistência aos danos mecânicos e o teor de lignina no tegumento das sementes de soja, determinando comportamento diferencial entre cultivares (Alvarez, 1994). Este mesmo autor concluiu que o conteúdo de lignina no tegumento da semente de soja apresenta-se maior nos cultivares com maior resistência ao dano mecânico. Valores superiores a 5\% de lignina no tegumento são bons indicativos de sementes com resistência ao dano mecânico.

Alvarez (1994) æparou as sementes dos cultivares FT-2, FT-10 e IAC-2, de acordo ao teor de lignina presentes no tegumento, conferindo-lhes diferentes 
comportamentos quanto à resistência aos danos mecânicos, sendo que o cultivar FT-2 possuía 6,19\% de lignina (maior resistência), FT-10 com 5,28\% (medianamente resistente) e IAC-2 com 4,21\% (menor resistência).

A lignificação do tegumento é uma característica relevante, pois confere resistência mecânica ao tecido e protege a parede celulósica do ataque de microorganismos.

A lignina é o terceiro maior componente da parede celular e o principal constituinte da substância intercelular, responsável pela manutenção da integridade e coesão estrutural das fibras vegetais (Cowling \& Kirk, 1976).

Muitos autores evidenciaram a variabilidade genética existente na soja quanto à resistência da semente ao dano mecânico (Agrawal \& Menon, 1974; Stanway, 1978; Paulsen, 1978; Costa et al., 1987; Krzyzanowski et al., 1989), como também metodologias para avaliação deste dano (Paulsen et al., 1981; França Neto et al., 1988; Bartsch et al., 1986). Entretanto, pouco se conhece sobre as metodologias capazes de selecionar genótipos de soja com semente resistente ao dano mecânico. Kueneman (1989) sugeriu o uso do "teste de queda" como metodologia de seleção em soja, tendo em vista o seu uso em sementes de feijão, nos Estados Unidos. Este teste é realizado com amostras de 100 sementes e baseia-se na queda livre individual das sementes de uma altura de $180 \mathrm{~cm}$, através de um tubo de polietileno apoiado sobre um prato de ferro inclinado a $12^{\circ}$, contra o qual as sementes se chocam.

No Brasil, métodos de laboratório para provocar danos mecânicos têm sido testados em sementes de soja. Carbonell et al. (1993), trabalhando com cultivares de soja, concluíram que o teste de queda não foi suficientemente drástico para produzir índices diferenciais confiáveis de dano mecânico entre os 
padrões de suscetibilidade e de resistência, que possibilite a sua utilização na seleção de genótipos resistentes para esta característica.

Carvalho et al. (1999) reportaram uma metodologia eficiente na determinação do dano e suas relações com a umidade e a posição da semente, através do uso de uma máquina impactadora, que pode ser utilizada em estudos básicos na identificação de diferenças varietais, para fins de determinação de padrões de resistência.

Carbonell \& Krzyzanowski (1995) propuseram o "teste do pêndulo", que através da queda livre de um pêndulo de aço sobre sementes individualizadas em alvéolos de um disco de aço, recebem um impacto de força conhecida; é uma metodologia que pode ser utilizada em programas de melhoramento de soja para caracterizar genótipos quanto à resistência a danos mecânicos. Utilizando a referida metodologia, os autores constataram maior resistência do cultivar FT-2 em relação aos cultivares FT-10 (medianamente resistente) e IAC-2 (pouco resistente). Relataram, ainda, que a melhor separação entre cultivares com diferentes suscetibilidades a danos mecânicos deu-se com a umidade de 13\% e altura de queda do pêndulo de $13 \mathrm{~cm}$.

D entre os testes utilizados para detectar danos mecânicos, o teste de tetrazólio tem se destacado, principalmente para soja, devido a sua rapidez e precisão. Este é capaz de identificar três tipos de danos mecânicos: rachaduras, amassamentos e abrasões (Krzyzanowski et al., 1999).

\subsection{Análise de Imagens}

A utilização da análise de imagens para a determinação de danos mecânicos em sementes destacase como uma eficiente ferramenta, pois se trata 
de um método de grande precisão (as sementes podem ser examinadas individualmente em imagens ampliadas que poderão indicar, em detalhes, a área danificada, sua extensão e localização) e não destrutivo. Desta maneira, as sementes submetidas à análise podem ser colocadas para germinar e permitir 0 estabelecimento de relações entre os danos mecânicos e os prejuízos causados para a germinação (Cícero et al., 1998).

A utilização de técnicas que sejam rápidas e precisas na identificação de injúrias ocorridas durante o processo de produção de sementes é de grande importância para a avaliação da qualidade das sementes antes da semeadura. 0 teste de raios-X, padronizado pela Associação Internacional de Análise de Sementes (ISTA, 1985), baseia-se no princípio da obtenção de imagens com 0 emprego de raios-X. Assim, ao atravessar as sementes, um feixe de raios- $\mathrm{X}$ cria uma imagem permanente dessas sobre um filme. As imagens podem apresentar maior ou menor grau de radiopacidade (claras) e radioluminescência (escuras) em função do nível de absorção dos raios-X pelas sementes, determinado pelos fatores de composição, espessura e densidade dos tecidos e comprimento de onda da radiação ionizante (Simak, 1980; ISTA, 1993).

Esta técnica foi inicialmente introduzida na Suécia, na década de 50, para a avaliação da qualidade de sementes de espécies florestais (Simak \& Gustafsson, 1953), sendo atualmente utilizado como teste de rotina para a avaliação da qualidade de sementes olerícolas (Liu et al., 1997; Van der Burg et al., 1994). Chavagnat \& Le Lezec (1984) concluíram que as imagens de raios-X propiciam informações sobre o tamanho e morfologia do embrião e sobre a quantidade de endosperma e de espaço livre no interior da semente. Nos últimos anos, tem sido sugerida a utilização da análise de imagens para 
caracterizar e detectar danos internos em sementes (Cícero et al., 1998; Carvalho et al., 2001; O bando-Flor, 2000).

Embora os raios- $X$ sejam potencialmente nocivos às sementes, a baixa dose absorvida durante 0 teste não causa mutações genéticas e não afeta a germinação das mesmas (Simak \& Gustafsson, 1953; Bino et al., 1993). Além disso, trata-se de um teste que não requer tratamento prévio das sementes, 0 que confere vantagens por ser um método não destrutivo, rápido e de simples execução. Em razão disso, o seu uso tem sido crescente, trazendo benefícios em diferentes etapas da produção e utilização das sementes, incluindo trabalhos de melhoramento genético.

A radiografia das sementes permite a visualização de injúrias mecânicas, danos por insetos e decorrentes de outros fatores adversos pré e pós-colheita, na forma de rachaduras ou fraturas (ISTA, 1993; Poulsen et al., 1998); possibilita ainda, a deteç̧ão de anormalidades em embriões, bem como a determinação do estádio de desenvolvimento dos mesmos (Simak, 1980).

0 método tem sido adotado na avaliação de sementes de Pinus spp (Simak, 1984; Sahlen et al., 1995), milho (Smith \& Grabe, 1985; Carvalho et al., 1999; Cícero et al., 1998; Obando-Flor, 2000), algumas cucurbitáceas (Kamra, 1966; Obando-Flor et al., 2001) e diversas espécies florestais (Swaminathan \& Kamra, 1961; Oliveira, 2000; Machado, 2002). 0 método possibilita, também, determinar a viabilidade de sementes. Nesse caso, o procedimento consiste em impregnar as sementes com agentes de contraste, como metais e água, previamente à radiografia das mesmas (Poulsen et al. 1998).

A inclusão do teste de raios-X nas Regras para Análise de Sementes (Brasil, 1992; ISTA, 1993) tem como objetivo básico à complementação das informações fornecidas pelo teste de germinação. Para tanto, as sementes são 
classificadas, de acordo com o perfil anatômico visualizado, em sementes cheias, vazias e danificadas, sendo as duas últimas categorias comumente verificadas em sementes de espécies florestais.

Entretanto, sementes anatomicamente perfeitas, conforme verificado no teste de raios- $X$, podem apresentar desempenho ineficiente durante a germinação. Tal fato pode ser verificado em decorrência de condições ambientais desfavoráveis à germinação, da presença de sementes com infecções latentes, sementes mortas por causas naturais, em estádios avançados de deterioração, ou submetidas a um armazenamento inadequado (Van der Burg et al., 1994).

Segundo a ISTA (1993), diferentes equipamentos de raios-X requerem tempos de exposição e níveis de intensidades diferentes para produzir a melhor imagem. As regulagens variam também para diferentes espécies. Assim, a qualidade ou poder de penetração dos raios- $\mathrm{X}$ é determinado pela quilovoltagem do aparelho de raios-X. O tempo de exposição, juntamente com a miliamperagem fixa do aparelho, regulam a quantidade de raios- $X$, que determina a densidade radiográfica ou grau de escurecimento. Nesse sentido, diferentes interações voltagem/tempo de exposição para a obtenção de imagens radiográficas apuradas em sementes têm sido adotadas em função da espécie, do aparelho de raios-X e da sensibilidade do filme radiográfico utilizado (ISTA, 1993). Na literatura pertinente são encontradas algumas referências sobre as condições de exposição das sementes à radiação para espécies florestais. As sementes da canafístula, por exemplo, foram mais bem visualizadas radiograficamente após exposição em um aparelho Faxitron, Hewlett-Packard (modelo 43855A) regulado a $25 \mathrm{kV} / 60$ segundos (Oliveira, 2000), enquanto 0 mesmo aparelho regulado a $20 \mathrm{kV} / 4$ minutos permitiu a obtenção de imagens 
radiográficas mais nítidas de sementes de cipreste italiano (Battisti et al., 2000). Por sua vez, a imagem radiográfica de sementes de Acada aunadifomis expostas às condições 20 kV/ 30 segundos com o uso de um aparelho Faxitron, HewlettPackard (modelo 43804N), permitiu uma visualização satisfatória de suas estruturas internas (Pukittayacamee \& Hellum, 1988). Sementes de tomate foram expostas a uma intensidade de $10 \mathrm{kV}$ por 3 minutos (Liu et al., 1997). Cícero et al. (1998), trabalhando com sementes de milho, utilizaram o aparelho $43805 \mathrm{~N} \mathrm{X-}$ Ray FAXITRON por 5 minutos e $15 \mathrm{kV}$; por outro lado, Obando-Flor (2000), utilizando o aparelho FAXITRON-HP, modelo 43805 A X, determinou o tempo de 45 segundos e $25 \mathrm{kV}$ para sementes da mesma espécie.

Cícero et al. (1998) e Carvalho et al. (1999) afirmaram que a análise radiográfica das sementes é um método eficiente para verificação de danos internos em sementes de milho. Girardin et al. (1993) e Carvalho et al. (1999), reforçaram a afirmação que a análise de imagens é o melhor método não destrutivo para avaliar as características morfológicas internas da semente.

Não foi encontrada na literatura nenhuma referência acerca de trabalhos envolvendo danos mecânicos em sementes de soja avaliados pela análise de imagens. Tais constatações levam à necessidade de pesquisas que possibilitem maiores esclarecimentos a respeito desse tema. 


\section{MATERIAL E MÉTODOS}

A pesquisa foi conduzida nos Laboratórios de Análise de Imagens e de Análise de Sementes, do Departamento de Produção Vegetal, da Escola Superior de Agricultura "Luiz de Queiroz", Universidade de São Paulo, em Piracicaba, SP, e na Empresa Brasileira de Pesquisa Agropecuária (Embrapa Soja), em Londrina, PR.

Foram utilizados os cultivares FT-2, FT-10 e IAC-2, cujas sementes apresentam diferentes teores de lignina no tegumento, conferindo-lhes diferentes comportamentos quanto à resistência aos danos mecânicos (Tabela 1), de acordo com a classificação de Alvarez (1994).

Tabela 1. Características dos cultivares FT-2, FT-10 e IAC-2 quanto à resistência aos danos mecânicos. Fonte: Alvarez (1994)

\begin{tabular}{ccc}
\hline Cultivar & Lignina (\%) & Índice de resistência a danos mecânicos \\
\hline FT-2 & 6,19 & 575 (resistente) \\
FT-10 & 5,28 & 400 (medianamente resistente) \\
IAC-2 & 4,21 & 266 (pouco resistente) \\
\hline
\end{tabular}

As sementes para o estudo foram produzidas na Fazenda Santa Terezinha, da EMBRAPA/ Centro Nacional de Pesquisa de Soja, em Londrina, PR, na safra 2001/2002. A colheita foi realizada arrancando-se manualmente as plantas, 
quando as sementes estavam no estádio de maturidade fisiológica (R7). Em seguida, foi retirado o restante das folhas das plantas e penduradas em varal dentro de um armazém ventilado, para perda gradativa de umidade, até atingir 0 teor de água aproximado de $20 \%$ na semente e, então, foi realizada a trilha manual, para a retirada das sementes das vagens, visando, assim, propiciar 0 mínimo de dano mecânico possível às sementes.

Após a trilha, as sementes foram colocadas dentro de sacos de filó para a secagem em um secador estacionário, com ar à temperatura ambiente, até atingir o teor de água desejado de 13\%. Os valores de umidade foram avaliados com 0 auxilio de um determinador de umidade digital de marca Burrows.

A uniformização do tamanho das sementes foi efetuada com o auxílio de peneiras, sendo que, para o cultivar IAC-2, como peneira superior utilizou-se uma de crivo circular com 7,0 mm de diâmetro e como peneira inferior a de 4,74 $\mathrm{mm}$, enquanto que para o cultivar FT-10 utilizou-se uma peneira de 7,25 mm como superior e como peneira inferior uma de 5,0 mm. Para o cultivar FT-10, foi utilizada uma peneira superior de 6,5 $\mathrm{mm}$ e inferior de 4,75 $\mathrm{mm}$. As sementes que atravessaram as peneiras superiores e ficaram retidas nas inferiores, foram submetidas a uma análise visual, para a retirada de todas as sementes danificadas (percevejo, umidade ou mecânico) e se constituíram no material utilizado na condução dos testes subseqüentes.

Para a determinação da qualidade inicial, as sementes dos três cultivares foram submetidas aos testes discriminados a seguir. 


\subsection{Teor de água das sementes}

Foi determinado pelo método de estufa a $105 \pm 3{ }^{\circ} \mathrm{C} / 24$ horas (Brasil, 1992). Os resultados, expressos em percentagem, foram calculados com base no peso úmido $(\mathrm{Bu})$.

\subsection{Teste de germinação}

Para avaliação da germinação, 200 sementes de cada cultivar, tomadas ao acaso, foram divididas em quatro sub-amostras de 50 sementes. Utilizou-se rolo de papel "germitest" como substrato e umedecimento com água equivalente a 2,5 vezes o seu peso. 0 germinador foi regulado a $25^{\circ} \mathrm{C}$ e as avaliações foram efetuadas seguindo-se os critérios estabelecidos pelas Regras para Análises de Sementes (Brasil, 1992).

\subsection{T este de tetrazólio}

Foram utilizadas duas sub-amostras de 50 sementes, por cultivar, tomadas ao acaso. As sementes foram pré-condicionadas em papel toalha convenientemente umedecido, durante 16 horas, em germinador a $25^{\circ} \mathrm{C}$. Decorrido esse período, as sementes foram colocadas em copinhos de plástico, sendo totalmente submersas na solução de tetrazólio a 0,075\%, durante 180 minutos, a $40^{\circ} \mathrm{C}$, no escuro, em germinador. Em seguida, as sementes foram lavadas e avaliadas individualmente, computando-se como número de sementes potencialmente germináveis aquelas incluídas nas classes de 1 a 5 e, como 
potencialmente vigorosas, aquelas incluídas nas classes 1 a 3 (França Neto et al., 1999).

\subsection{Teste de envelhecimento acelerado}

Utilizaram-se 42 g de sementes (200 a 250 sementes) de cada cultivar, colocadas em caixas plásticas de germinação, sobre uma tela de aço inox, contendo $40 \mathrm{ml}$ de água deionizada, que foram mantidas em câmara de envelhecimento sob $42^{\circ} \mathrm{C}$ e $100 \%$ de umidade relativa do ar (Marcos Filho, 1999). Após 48 horas, as sementes foram colocadas para germinar da mesma maneira descrita para o teste de germinação. A avaliação de plântulas normais foi realizada conforme a prescrição das Regras para Análise de Sementes (Brasil, 1992).

\subsection{T este de condutividade elétrica}

Foi realizado com quatro sub-amostras de 50 sementes por cultivar, as quais foram pesadas e colocadas para embeber em copo plástico com $75 \mathrm{ml}$ de água deionizada durante 24 horas a $25{ }^{\circ} \mathrm{C}$ (Vieira \& Krzyzanowski, 1999). Após a embebição, foi realizada a leitura em condutivímetro DIGIMED, Modelo DM31. O valor obtido, dividido pelo peso das 50 sementes, foi expresso em ì mhos.cm ${ }^{-1} \cdot g^{-1}$. 


\subsection{Teste de emergência de plântulas}

O teste foi conduzido em bandejas plásticas de 48x33×10 cm, com quatro sub-amostras de 50 sementes por cultivar, utilizando-se como substrato terra e areia na proporção de 1:2, respectivamente, mantidas em casa de-vegetação, sob temperatura ambiente e com irrigação diária por sistema de microaspersão. A avaliação foi realizada 14 dias após a semeadura, computando-se a porcentagem de plântulas emergidas.

\subsection{D anificação das sementes através do teste do pêndulo}

Após a determinação da qualidade fisiológica inicial, 200 sementes de cada cultivar, foram separadas em duas sub-amostras (A e B) de 100 sementes. A subamostra $\mathrm{A}$ foi destinada à análise de imagens e a sub-amostra $\mathrm{B}$ ao teste de tetrazólio. $\mathrm{Na}$ seqüência, objetivando causar diferentes tipos de danos mecânicos, todas essas sementes (sub-amostras A e B) foram submetidas ao teste do pêndulo, o qual baseia-se na queda livre de um pêndulo metálico a uma altura de $13 \mathrm{~cm}$ sobre as sementes distribuídas individualmente em alvéolos de um disco metálico (Carbonell, 1991), o que corresponde a uma energia cinética aplicada sobre a semente, de 0,3185 joule (Figura 1).

Os danos produzidos nas sementes da sub-amostra A foram similares aos da sub-amostra B, o que possibilitou estabelecer as comparações entre os dois métodos (análise de imagens e tetrazólio). Foram provocados danos mecânicos em 6 regiões distintas das sementes (Figura 2), provocando-se o mesmo tipo de dano para cada região $(A, B, C, D, E, F)$ em duas repetições de 50 sementes para cada sub-amostra (A e B). 
A seguir, as sementes foram colocadas em placas com células individualizadas (numeradas), de maneira que pudessem ser identificadas nas determinações posteriores.

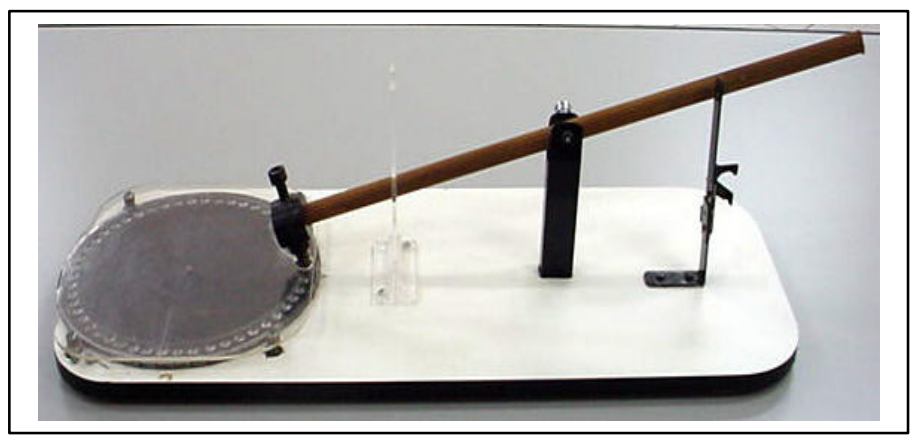

Figura 1 - D anificador Mecânico utilizado para provocar danos no teste do pêndulo Fonte: Carbonell, 1991 

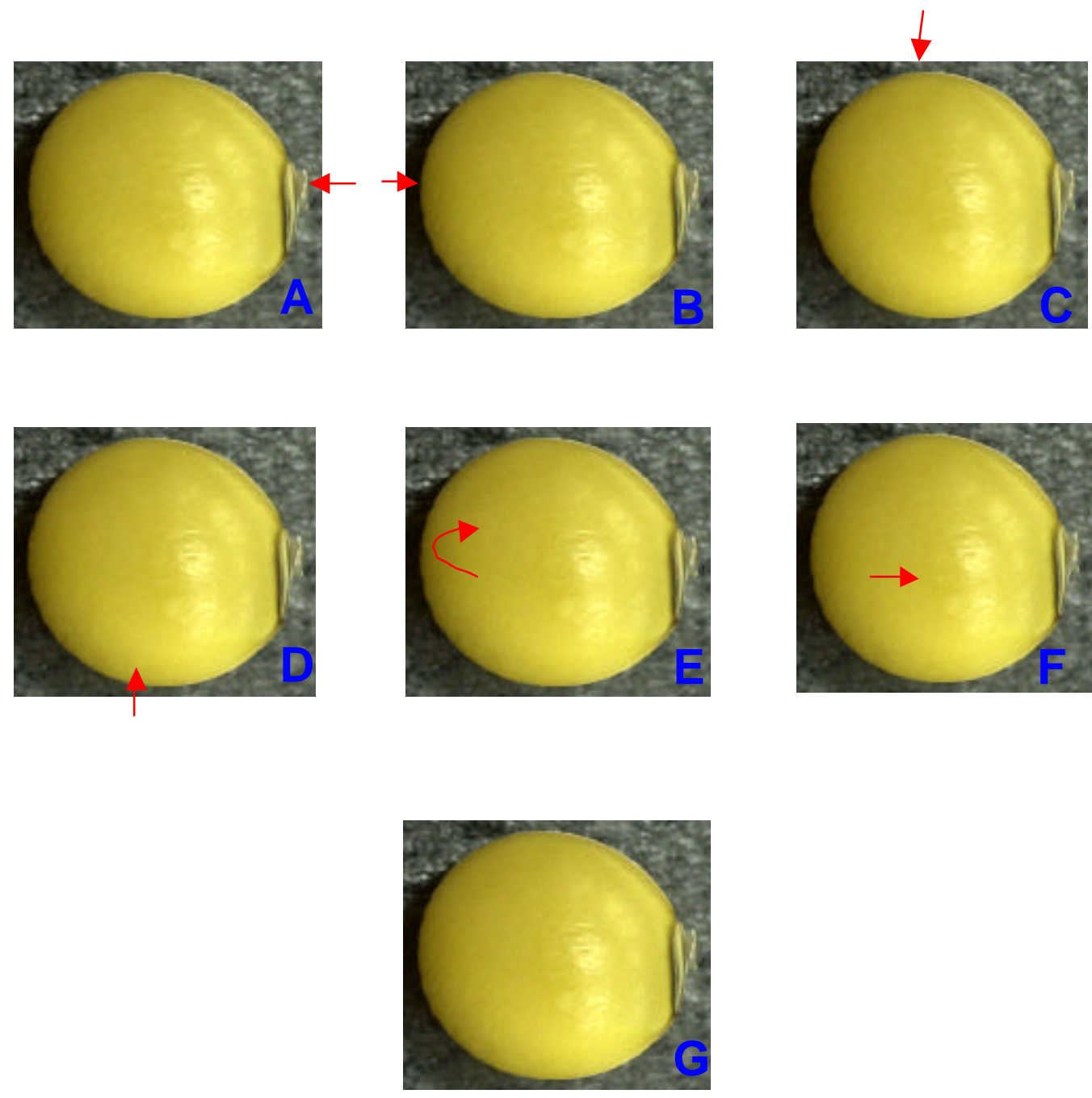

Figura 2 - Fotos das sementes de soja, indicando os locais de impacto provocado pelo "teste do pêndulo": A: no hilo; B: na parte oposta ao hilo; C: na plúmula (parte superior da semente); D: na parte oposta à plúmula; E: sobre 0 cotilédone esquerdo; F: sobre o cotilédone direito; G: Testemunha, semente sem dano 


\subsection{Detecção dos danos mecânicos por meio da análise de imagens}

Para a detecção de danos externos, as sementes da sub-amostra A foram posicionadas de maneira a evidenciar os danos, sendo fotografadas individualmente, utilizando-se uma câmera digital Nikon, modelo D1, acoplada a um computador Pentium III (600 MHZ, memória de 256 MB, HD Ultra SCSI de $20 \mathrm{~GB}$ e monitor de 21 polegadas).

Para a detecção dos danos mecânicos internos, as mesmas sementes (fotografadas anteriormente) foram submetidas ao teste de raios-X. Colocou-se 100 sementes (2 repetições de 50) em alvéolos individualizados de uma placa acrílica, colocando-se por baixo uma fita adesiva transparente para poder fixar a semente em posição adequada. D evido à pouca visibilidade do eixo embrionário nas radiografias (pela pouca diferença de contraste entre o eixo embrionário e os cotilédones), foram realizados testes de posicionamento da semente com relação à incidência dos raios-X e obteve-se melhores resultados quando o eixo embrionário ficava em ângulo de $45^{\circ}$ em relação à placa (Figura 3).

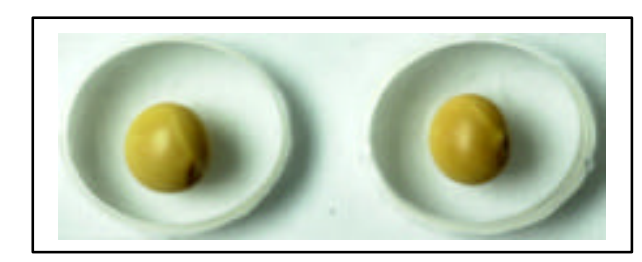

Figura 3 - Semente de soja, indicando a posição para realizar o teste de raios-X

Para a obtenção da radiografia, a placa de acrílico com as sementes foi colocada diretamente sobre um filme radiográfico (Kodak MIN-R 2000, tamanho de $18 \times 24 \mathrm{~cm}$ ) a uma distância de $40 \mathrm{~cm}$ da fonte de radiação. 0 aparelho de Raios-X utilizado foi o FAXITRON Hewlett-Packard, modelo MX-20. 
O tempo de exposição e a intensidade de radiação que possibilitaram melhor visualização de danos mecânicos internos em sementes de soja, foram determinados em ensaios preliminares, determinando-se como os mais adequados a intensidade de $20 \mathrm{kV}$ e 0 tempo de exposição de 45 segundos.

Os filmes radiográficos foram revelados em uma processadora automática Hope X-Ray, modelo 319 micro-Max. A seguir, as imagens dos filmes foram capturadas (uma a uma) por um Scanner Umax modelo Power LooK 1100, para a amplificação e melhor visualização no mesmo computador descrito anteriormente.

Com o intuito de avaliar os danos mecânicos detectados pela análise de imagens, as sementes de cada cultivar, previamente numeradas (identificadas) foram submetidas ao teste de germinação (Brasil, 1992), mediante a utilização de substrato de rolo de papel-toalha, umedecido com quantidade de água equivalente a 2,5 vezes o seu peso, em temperatura de $25^{\circ} \mathrm{C}$. As sementes foram semeadas em grupo de 10 (no terço superior do substrato, para permitir 0 desenvolvimento das plântulas de maneira individualizada). A interpretação foi efetuada aos 5 e 8 dias após a semeadura, de acordo com as Regras de Análise de Sementes (Brasil, 1992). Em seguida foram fotografadas individualmente todas as plântulas normais, anormais e as sementes que não germinaram, utilizando-se a câmera digital acoplada ao computador (descrito anteriormente). Desta maneira, todas as imagens puderam ser examinadas simultaneamente na tela do monitor, permitindo fazer um diagnóstico para cada uma delas.

Os danos mecânicos observados na análise radiográfica (avaliação interna) das sementes, receberam notas de acordo aos critérios contidos na Tabela 2, seguindo a classificação feita por Cícero et al. (1998) para sementes de milho e modificado para sementes de soja. 
Assim puderam ser avaliadas todas as imagens: análise visual da semente (morfologia externa), analise radiográfica (morfologia intema), com suas respectivas notas (níveis de dano) e plântula ou semente morta.

Tabela 2. Critérios utilizados para caracterizar as notas para os níveis de danos mecânicos observados no eixo embrionário e nos cotilédones das sementes de soja através das imagens de raios-X

\begin{tabular}{ccc}
\hline Nível de dano & Eixo embrionário & Cotilédones \\
\hline Não observado & 1 & 1 \\
Não severo & 2 & 2 \\
Severo & 3 & 3 \\
\hline
\end{tabular}

\subsection{Detecção dos danos mecânicos por meio do teste de tetrazólio}

As sementes da sub-amostra B foram précondicionadas em papel-toalha umedecido, durante 16 horas, em germinador a $25^{\circ} \mathrm{C}$. D ecorrido esse período as sementes foram colocadas em copinhos de plástico, submersas na solução de tetrazólio a $0,075 \%$ durante 180 minutos a $40^{\circ} \mathrm{C}$, no escuro em estufa. Após 0 desenvolvimento da coloração, as sementes foram fotografadas pela mesma câmera digital descrita anteriormente e disponibilizadas em computador (descrito anteriormente). A avaliação foi realizada seguindo os critérios estabelecidos por França Neto et al. (1999).

\subsection{Análise dos resultados e procedimento estatístico}

Os resultados foram analisados de forma comparativa, procurando-se relacionar os danos mecânicos detectados pela análise de imagens (semente por 
semente) com as possíveis anormalidades das plântulas e ou sementes mortas. Também foram estabelecidas comparações entre o método de análise de imagens e 0 teste de tetrazólio por meio da análise de correlação. A análise estatística foi realizada em esquema fatorial 3 x 7 (três cultivares e sete regiões de dano nas sementes), com duas repetições de 50 sementes.

Os dados referentes aos testes de germinação, envelhecimento acelerado e emergência de plântulas em campo foram transformados em arc seno da raíz quadrada de x/ 100; os dados de condutividade elétrica não foram transformados. Esses testes foram submetidos à análise estatística com quatro repetições, utilizando-se 0 delineamento inteiramente casualizado. A análise foi realizada empregando o sistema SANEST para computadores (Zonta \& Machado, 1984). As médias foram comparadas pelo teste de Tukey com $5 \%$ de probabilidade. 


\section{RESULTADOS E DISCUSSÃO}

\subsection{Avaliação da qualidade inicial das sementes}

Os dados referentes ao grau de umidade das sementes (Tabela 3) foram semelhantes para os três cultivares estudados. Esse fato é importante para a execução dos testes, pois a uniformização do teor de água das sementes é imprescindível para a padronização das avaliações (Marcos Filho et al., 1987).

Os testes de germinação, de envelhecimento acelerado e de emergência de plântulas (Tabela 3) indicaram que as sementes dos cultivares FT-2 e FT-10 apresentaram potencial fisiológico superior em relação ao cultivar IAC-2. Segundo Marcos Filho et al. (1987), o teste de emergência de plântulas constitui um parâmetro indicador da eficiência de outros testes de vigor para avaliação do potencial fisiológico de lotes de sementes.

$\mathrm{O}$ teste de condutividade elétrica (Tabela 3) indicou que o cultivar FT-2 apresentou melhor potencial fisiológico em relação ao cultivar FT-10 que, por sua vez, apresentou superioridade em relação ao cultivar IAC-2. Este teste tem sido proposto para avaliar o vigor de sementes em função da quantidade de lixiviados na solução de embebição e está diretamente relacionado com a integridade das membranas celulares (Matthews \& Powell, 1981; Marcos Filho et al., 1987; Vieira \& Krzyzanowski, 1999). Dessa maneira, membranas mal estruturadas e células danificadas estão, geralmente, associadas com o processo 
de deterioração da semente e, portanto, com sementes de baixo vigor (AOSA, 1983).

Tabela 3. Avaliação da qualidade inicial das sementes dos três cultivares estudados: grau de umidade $(\mathrm{GU})$, teste de germinação $(\mathrm{TG})$, condutividade elétrica $(\mathrm{CE})$, envelhecimento acelerado (EA) e teste de emergência de plântulas (EP)

\begin{tabular}{cccccc}
\hline Cultivar & GU (\%) & TG (\%) & CE (i mhos.cm $\left.{ }^{1} \cdot g^{1}\right)$ & EA (\%) & EP (\%) \\
\hline FT-2 & $13,4 \mathrm{a}$ & $90 \mathrm{a}$ & $348 \mathrm{a}$ & $90 \mathrm{a}$ & $88 \mathrm{a}$ \\
FT-10 & $13,1 \mathrm{a}$ & $92 \mathrm{a}$ & $416 \mathrm{~b}$ & $88 \mathrm{a}$ & $90 \mathrm{a}$ \\
IAC-2 & $13,3 \mathrm{a}$ & $82 \mathrm{~b}$ & $524 \mathrm{c}$ & $80 \mathrm{~b}$ & $78 \mathrm{~b}$ \\
& & & & & \\
CV (\%) & 6,38 & 8,54 & 10,43 & 9,14 & 9,68
\end{tabular}

Na coluna, médias seguidas da mesma letra não diferem entre si pelo teste de Tukey a 5\% de probabilidade

Na Tabela 4 são apresentados os dados relativos ao teste de tetrazólio; assim, verificase que as sementes dos três cultivares não apresentaram diferença estatística na escala de danos mecânicos 1-8 (danos mecânicos leves) e nem na escala 6-8 (danos mecânicos severos). A explicação para esta uniformidade está no fato de que as condições de trilha foram as mesmas para os três cultivares.

Na variável dano por umidade (Tabela 4), os cultivares FT-2 e FT-10 apresentaram maiores ńdices em relação ao cultivar IAC-2 na escala 1-8; já na escala 6-8, tanto o cultivar FT-10 como o IAC-2 apresentaram menores valores do que 0 cultivar FT-2. 
Com relação aos danos por percevejo (Tabela 4), para os danos totais (18) e severos (6-8), os cultivares FT-2 e FT-10 apresentaram menor incidência em relação ao cultivar IAC-2.

No teste de viabilidade (TZ 1-5), observado na Tabela 4, verifica se que 0 cultivar IAC-2 se mostrou estatisticamente inferior aos outros dois cultivares. Para os valores médios de vigor (TZ 1-3), verificase que o cultivar FT-10 apresentou maior nível do que os cultivares FT-2 e IAC-2.

Tabela 4. Avaliação da qualidade inicial das sementes dos três cultivares estudados: teste de tetrazólio - danos mecânicos (D M), danos por umidade (DU), danos por percevejo (DP), viabilidade e vigor

\begin{tabular}{|c|c|c|c|c|c|c|c|c|}
\hline \multirow[t]{2}{*}{ Cultivar } & \multicolumn{2}{|c|}{ D M (\%) } & \multicolumn{2}{|c|}{ DU (\%) } & \multicolumn{2}{|c|}{ DP (\%) } & \multirow{2}{*}{$\frac{\text { Viabilidade (\%) }}{1-5}$} & \multirow{2}{*}{$\begin{array}{c}\text { Vigor }(\%) \\
1-3 \\
\end{array}$} \\
\hline & $1-8$ & $6-8$ & $1-8$ & 6-8 & $1-8$ & $6-8$ & & \\
\hline FT-2 & $5 a$ & $2 a$ & $96 a$ & $4 a$ & $12 \mathrm{~b}$ & $1 \mathrm{~b}$ & $94 a$ & $76 \mathrm{~b}$ \\
\hline FT-10 & $4 a$ & $1 \mathrm{a}$ & $95 \mathrm{a}$ & $1 b$ & $13 b$ & $0 \mathrm{~b}$ & $96 a$ & $82 \mathrm{a}$ \\
\hline IAC-2 & $2 a$ & $0 \mathrm{a}$ & $86 \mathrm{~b}$ & $2 b$ & $59 a$ & $4 a$ & $88 \mathrm{~b}$ & $76 \mathrm{~b}$ \\
\hline CV (\%) & 10,34 & 7,43 & 10,86 & 8,36 & 11,54 & 7,98 & 8,62 & 8,84 \\
\hline
\end{tabular}

Na coluna, médias seguidas da mesma letra não diferem entre si pelo teste de Tukey a $5 \%$ de probabilidade

A análise comparativa dos dados relativos à avaliação da qualidade inicial das sementes em estudo indicou que, de maneira geral, os testes separaram, de maneira consistente, diferenças acentuadas no potencial fisiológico das sementes. Assim, pode-se afirmar que sementes dos cultivares FT-2 e FT-10 apresentaram potencial fisiológico superior em relação ao cultivar IAC-2. 


\subsection{Avaliação de danos mecânicos pela análise de imagens}

O exame simultâneo das imagens das sementes (externas e internas), e das plântulas e sementes mortas, provenientes do teste de germinação, permitiu proceder a um diagnóstico para cada caso estudado. No presente trabalho, se fossem levados em conta apenas os exames das imagens externas das sementes, as imprecisões do diagnóstico seriam evidentes, pois dessa maneira seria possível apenas verificar danos no tegumento.

Assim, foi realizada a análise de imagens para avaliar os danos mecânicos externos utilizando os critérios propostos por Cícero et al. (1998), os quais classificaram em notas: dano não observado (nota 1), dano não severo (nota 2) e dano severo (nota 3).

$\mathrm{Na}$ Tabela 5 são apresentados os resultados relativos aos danos observados nas imagens externas das sementes dos três cultivares. Assim, pode se observar que houve diferenças entre as notas atribuídas às sementes dos três cultivares, sendo que o cultivar menos suscetível ao dano mecânico (FT-2), apresentou menores índices de danos severos (nota 3) e índices mais altos de sementes sem danos externos (nota 1) independentemente do local onde os danos foram provocados.

No cultivar FT-10, as regiões danificadas no hilo, na plúmula e no cotilédone direito tiveram os comportamentos semelhantes, apresentando valores de danos severos (nota 3) estatisticamente inferiores.

O cultivar IAC-2 (menor resistência ao dano mecânico) apresentou maior porcentagem de sementes com danos severos (nota 3) na região com danos mecânicos provocados no cotilédone esquerdo . 
Tabela 5. Valores médios (\%) de sementes com diferentes intensidades de danos mecânicos, nos três cultivares estudados, avaliadas através da análise das imagens externas, nos diferentes locais onde os danos mecânicos foram provocados

\begin{tabular}{|c|c|c|c|c|}
\hline \multirow[t]{2}{*}{ Local de D ano } & \multirow[b]{2}{*}{ Nota } & \multicolumn{3}{|c|}{ CULTIVAR } \\
\hline & & FT-2 & FT-10 & IAC-2 \\
\hline \multirow{3}{*}{ Hilo } & $1^{1}$ & $62 \mathrm{a}$ & $69 a$ & $58 \mathrm{a}$ \\
\hline & $2^{2}$ & $28 \mathrm{~b}$ & $20 \mathrm{~b}$ & $16 \mathrm{c}$ \\
\hline & $3^{3}$ & $10 \mathrm{c}$ & $11 \mathrm{c}$ & $26 \mathrm{~b}$ \\
\hline \multirow{3}{*}{ Oposta ao hilo } & 1 & $56 a$ & $48 \mathrm{a}$ & $49 a$ \\
\hline & 2 & $27 \mathrm{~b}$ & $26 \mathrm{~b}$ & $20 \mathrm{c}$ \\
\hline & 3 & $17 \mathrm{c}$ & $26 \mathrm{~b}$ & $31 \mathrm{~b}$ \\
\hline \multirow{3}{*}{ Plúmula } & 1 & $74 a$ & $76 a$ & $52 \mathrm{a}$ \\
\hline & 2 & $24 \mathrm{~b}$ & $21 \mathrm{~b}$ & $19 \mathrm{c}$ \\
\hline & 3 & $02 \mathrm{c}$ & $03 \mathrm{c}$ & $29 \mathrm{~b}$ \\
\hline \multirow{3}{*}{ O posta à plúmula } & 1 & $75 a$ & $69 a$ & $54 \mathrm{a}$ \\
\hline & 2 & $16 \mathrm{~b}$ & $15 \mathrm{~b}$ & $22 \mathrm{~b}$ \\
\hline & 3 & $09 \mathrm{c}$ & $16 \mathrm{~b}$ & $24 \mathrm{~b}$ \\
\hline \multirow{3}{*}{ Cotilédone esquerdo } & 1 & $59 a$ & $58 \mathrm{a}$ & $28 \mathrm{~b}$ \\
\hline & 2 & $40 \mathrm{~b}$ & $20 \mathrm{~b}$ & $36 a$ \\
\hline & 3 & $07 \mathrm{c}$ & $22 \mathrm{~b}$ & $36 \mathrm{a}$ \\
\hline \multirow{3}{*}{ Cotilédone direito } & 1 & $52 \mathrm{a}$ & $70 a$ & $24 \mathrm{c}$ \\
\hline & 2 & $40 \mathrm{~b}$ & $22 b$ & $41 \mathrm{a}$ \\
\hline & 3 & $08 \mathrm{c}$ & $08 \mathrm{c}$ & $35 \mathrm{~b}$ \\
\hline CV (\%) & & 7,34 & 6,97 & 7,83 \\
\hline
\end{tabular}

Médias seguidas da mesma letra, na coluna e para cada local de dano, não diferem entre si pelo teste de Tukey a $5 \%$ de probabilidade

${ }^{1}$ D ano não observado, ${ }^{2}$ D ano não severo, ${ }^{3}$ D ano severo

Por outro lado, a análise radiográfica foi realizada com 0 intuito de verificar a existência de possíveis danos internos nas sementes, permitindo observar danos no eixo embrionário e nos cotilédones. Assim, utilizando os 
critérios para caracterizar os danos mecânicos presentes no eixo embrionário e nos cotilédones (Cícero et al. 1998), foram obtidos os dados contidos na Tabela 6. Desta forma, pode-se observar que, no cultivar FT-2, o eixo embrionário em todos os locais de dano, apresentou valores significativamente mais altos de sementes que não apresentaram nenhum dano interno (nota 1) quando comparados com as notas 2 e 3 (dano não severo e dano severo, respectivamente). Ainda, considerando o eixo embrionário, quando os danos foram provocados nos cotilédones esquerdo e direito, verificaram-se as menores porcentagens de sementes com danos severos e não severos, sendo que nesses casos, o efeito do impacto do pêndulo ficou mais restrito aos cotilédones. Quando são analisados os dados referentes aos danos observados nos cotilédones, observase que as sementes tiveram as menores porcentagens de sementes com danos severos independentemente dos locais onde os danos foram provocados. As regiões com maiores índices de sementes que não apresentaram danos nos cotilédone (nota 1) foram as sementes com dano na plúmula e na região oposta à plúmula.

Por outro lado, no cultivar FT-10, quando foi avaliado o eixo embrionánio, as sementes com danos no hilo, na plúmula, no cotilédone esquerdo e no cotilédone direito tiveram um comportamento semelhante, apresentando valores significativamente inferiores de danos severos (nota 3). Enquanto que as sementes com danos nas regiões opostas ao hilo e à plúmula tiveram as porcentagens mais altas de danos severos. Estes resultados levam a pensar que as sementes que recebiam o impacto do pêndulo nos referidos locais, tanto o hilo quanto à plúmula ficavam em contato com o alvéolo do disco metálico (duplamente danificadas), afetando severamente a semente. Quando os danos foram provocados nos cotilédones esquerdo e direito, não houve 
manifestação de danos severos no eixo embrionário (nota 3) que, por sua vez, apresentaram maiores porcentagens de sementes sem dano (nota 1). Quando são observados os danos nos cotilédones para este mesmo cultivar (FT-10), todos os locais de dano apresentaram significativamente menores índices de danos severos (nota 3).

No cultivar IAC-2, os resultados para a análise de danos no eixo embrionário indicam que maiores porcentagens de sementes sem danos (nota 1), em relação aos danos não severos e severos, foram obtidas em todos os locais onde os danos foram provocados. Por outro lado, menores índices de porcentagem de danos severos (nota 3) foram observados nas sementes com danos provocados no hilo, na plúmula, e na região oposta à plúmula. Nos cotilédones os valores mais altos de sementes sem dano (nota 1) foram obtidos nas sementes com danos provocados no hilo, na região oposta ao hilo, na plúmula e na região oposta à plúmula. Os danos severos (nota 3) foram mais expressivos nas sementes com danos nas regiões dos cotilédones esquerdo e direito.

De maneira geral, houve diferenças estatísticas entre os danos (não observado, não severo e severo) independentemente do local onde o dano foi provocado, sendo que os danos provocados sobre os cotilédones esquerdo e direito proporcionaram menores porcentagens de danos severos. Tal comportamento pode ser explicado pelo fato dos danos provocados nos referidos locais não terem apresentado uma dispersão acentuada do dano na semente.

Assim, o teste de raios- $\mathrm{X}$ detectou danos internos não observados pela análise das imagens externas, concordando com vários autores que têm sugerido a utilização da análise de imagens digitais de raios-X para caracterizar e detectar 
danos intemos em sementes (Cícero et al., 1998; Carvalho et al., 1999; ObandoFlor, 2000).

Tabela 6. Valores médios (\%) de sementes com diferentes intensidades de danos mecânicos no eixo embrionário (EE) e nos cotilédones (C), nos três cultivares estudados, avaliadas através da análise radiográfica, nos diferentes locais onde os danos mecânicos foram provocados

\begin{tabular}{|c|c|c|c|c|c|c|c|}
\hline \multirow[t]{2}{*}{ Local de dano } & \multirow[b]{2}{*}{ Nota } & \multicolumn{2}{|c|}{ FT-2 } & \multicolumn{2}{|c|}{ FT-10 } & \multicolumn{2}{|c|}{ IAC-2 } \\
\hline & & $\mathrm{EE}$ & $\mathrm{C}$ & $\mathrm{EE}$ & $\mathrm{C}$ & $\mathrm{EE}$ & $\mathrm{C}$ \\
\hline \multirow{3}{*}{ Hilo } & $1^{1}$ & $60 a$ & $47 a$ & $49 a$ & $72 a$ & $55 a$ & $51 \mathrm{a}$ \\
\hline & $2^{2}$ & $14 \mathrm{c}$ & $40 \mathrm{~b}$ & $37 \mathrm{~b}$ & $26 \mathrm{~b}$ & $29 \mathrm{~b}$ & $22 \mathrm{~b}$ \\
\hline & $3^{3}$ & $26 \mathrm{~b}$ & $13 \mathrm{c}$ & $14 \mathrm{c}$ & $01 \mathrm{c}$ & $16 \mathrm{c}$ & $27 \mathrm{c}$ \\
\hline \multirow{3}{*}{ Oposta ao hilo } & 1 & $59 a$ & $37 \mathrm{~b}$ & $32 \mathrm{~b}$ & $39 \mathrm{~b}$ & $40 a$ & $43 a$ \\
\hline & 2 & $24 \mathrm{~b}$ & $41 \mathrm{a}$ & $37 \mathrm{a}$ & $47 a$ & $29 \mathrm{~b}$ & $33 \mathrm{~b}$ \\
\hline & 3 & $17 \mathrm{C}$ & $22 \mathrm{c}$ & $31 \mathrm{~b}$ & $14 \mathrm{c}$ & $31 \mathrm{~b}$ & $24 \mathrm{c}$ \\
\hline \multirow{3}{*}{ Plúmula } & 1 & $41 \mathrm{a}$ & $90 a$ & $63 a$ & $75 a$ & $39 a$ & $80 a$ \\
\hline & 2 & $36 \mathrm{~b}$ & $08 \mathrm{~b}$ & $27 \mathrm{~b}$ & $24 \mathrm{~b}$ & $35 \mathrm{~b}$ & $19 \mathrm{~b}$ \\
\hline & 3 & $23 \mathrm{c}$ & $02 \mathrm{c}$ & $10 \mathrm{c}$ & $01 \mathrm{c}$ & $26 \mathrm{c}$ & $01 \mathrm{c}$ \\
\hline \multirow{3}{*}{ O posta à plúmula } & 1 & $55 a$ & $90 a$ & $45 a$ & $83 \mathrm{a}$ & $49 a$ & $70 \mathrm{a}$ \\
\hline & 2 & $26 \mathrm{~b}$ & $10 \mathrm{~b}$ & $28 \mathrm{~b}$ & $14 \mathrm{~b}$ & $34 \mathrm{~b}$ & $27 \mathrm{~b}$ \\
\hline & 3 & $19 \mathrm{c}$ & $00 \mathrm{c}$ & $27 \mathrm{~b}$ & $03 \mathrm{c}$ & $17 \mathrm{c}$ & $03 \mathrm{c}$ \\
\hline \multirow{3}{*}{ Cotilédone esquerdo } & 1 & $91 \mathrm{a}$ & $27 \mathrm{~b}$ & $79 a$ & $35 \mathrm{~b}$ & $64 \mathrm{a}$ & $05 \mathrm{c}$ \\
\hline & 2 & $08 \mathrm{~b}$ & $69 a$ & $21 \mathrm{~b}$ & $58 \mathrm{a}$ & $18 \mathrm{~b}$ & $43 \mathrm{~b}$ \\
\hline & 3 & $01 \mathrm{c}$ & $04 \mathrm{c}$ & $00 \mathrm{c}$ & $07 \mathrm{c}$ & $18 \mathrm{~b}$ & $52 \mathrm{a}$ \\
\hline \multirow{3}{*}{ Cotilédone direito } & 1 & $91 \mathrm{a}$ & $25 \mathrm{~b}$ & $78 a$ & $54 \mathrm{a}$ & $47 a$ & $09 \mathrm{c}$ \\
\hline & 2 & $06 \mathrm{~b}$ & $74 \mathrm{a}$ & $22 \mathrm{~b}$ & $46 \mathrm{~b}$ & $28 \mathrm{~b}$ & $43 \mathrm{~b}$ \\
\hline & 3 & $03 \mathrm{~b}$ & $01 \mathrm{c}$ & $00 \mathrm{c}$ & $00 \mathrm{c}$ & $25 \mathrm{~b}$ & $48 a$ \\
\hline CV (\%) & & 9,16 & 8,34 & 9,04 & 9,75 & 6,76 & 8,05 \\
\hline
\end{tabular}

Médias seguidas da mesma letra, na coluna e para cada local de dano, não diferem entre si pelo teste de Tukey a $5 \%$ de probabilidade

${ }^{1} \mathrm{D}$ ano não observado, ${ }^{2} \mathrm{D}$ ano não severo, ${ }^{3} \mathrm{D}$ ano severo

D urante a avaliação das imagens internas (raios-X), foram observadas, nos três cultivares, sementes que não evidenciavam diferenças visuais entre 0 eixo 
embrionário e os cotilédones e nem apresentavam danos mecânicos. Assim, essas sementes foram computadas e analisadas, separadamente, quanto às respectivas plântulas normais, anormais e sementes mortas resultantes do teste de germinação (Tabela 7).

As sementes, dos três cultivares, com danos provocados sobre os cotilédones esquerdo e direito apresentaram menores porcentagens de sementes nas quais não foi possível observar o eixo embrionánio nem os danos internos (Tabela 7).

As sementes que não sofreram danificações mecânicas (testemunha) apresentaram maiores porcentagens de sementes na qual não foi possível diferenciar o eixo embrionário dos cotilédones (Tabela 7).

Nessa mesma Tabela são observadas as porcentagens de plântulas normais avaliadas pelo teste de germinação das sementes nas quais não foi possível observar o eixo embrionário nem algum tipo de dano intemo. Os resultados mostram que o tratamento testemunha apresentou maiores porcentagens de plântulas normais, nos três cultivares, quando comparados com as sementes dos demais tratamentos.

Esses resultados levam a pensar que uma das causas para a pouca visibilidade do eixo embrionário das sementes de soja nas radiografias, é a pouca diferença de contraste existente entre 0 eixo embrionário e os cotilédones. Por esse motivo, foram realizados testes de posicionamento da semente em relação à incidência dos raios- $X$, sendo que os melhores resultados foram obtidos, quando o eixo embrionário se posicionou em ângulo de $45^{\circ}$ em relação à placa (Figura 3). Quando o dano (mecânico, umidade ou percevejo) é produzido em uma semente, esse dano produz uma diferença de contraste na semente, possibilitando assim a observação da estrutura interna e dos danos existentes. 
Tabela 7. Valores médios (\%) de plântulas normais (PN), de plântulas anormais (PA) e de sementes mortas (SM) provenientes de sementes dos três cultivares estudados, as quais não evidenciavam diferenças visuais entre o eixo embrionário e os cotilédones e nem apresentavam danos mecânicos nas imagens radiográficas

Local de dano

\begin{tabular}{|c|c|c|c|c|c|c|c|c|c|c|c|c|}
\hline & \multicolumn{12}{|c|}{ CULTIVAR } \\
\hline & \multicolumn{4}{|c|}{ FT-2 } & \multicolumn{4}{|c|}{ FT-10 } & \multicolumn{4}{|c|}{ IAC-2 } \\
\hline & $\mathrm{PN}$ & $\mathrm{PA}$ & SM & Total & PN & $\mathrm{PA}$ & SM & Total & $\mathrm{PN}$ & $\overline{P A}$ & SM & Total \\
\hline Hilo & 13 & 05 & 01 & 19 & 03 & 02 & 01 & 06 & 10 & 00 & 01 & 11 \\
\hline Oposta ao hilo & 03 & 08 & 02 & 13 & 06 & 01 & 00 & 07 & 08 & 01 & 01 & 10 \\
\hline Plúmula & 12 & 02 & 00 & 14 & 26 & 03 & 01 & 30 & 08 & 02 & 01 & 11 \\
\hline O posta à plúmula & 14 & 03 & 00 & 17 & 14 & 01 & 01 & 16 & 04 & 02 & 00 & 06 \\
\hline $\begin{array}{l}\text { Cotilédone } \\
\text { esquerdo }\end{array}$ & 06 & 01 & 01 & 08 & 04 & 00 & 01 & 05 & 01 & 00 & 00 & 01 \\
\hline Cotilédone direito & 01 & 00 & 00 & 01 & 04 & 01 & 00 & 05 & 00 & 00 & 00 & 00 \\
\hline Testemunha & 33 & 02 & 00 & 35 & 33 & 01 & 01 & 35 & 12 & 02 & 03 & 17 \\
\hline Médias & 12 & 03 & 01 & 16 & 14 & 01 & 01 & 16 & 06 & 01 & 01 & 08 \\
\hline
\end{tabular}

Na Tabela 8 encontram-se as médias de plântulas normais dos três cultivares, obtidas após a obtenção das imagens externas e internas das sementes. 0 exame da referida tabela permite verificar que a germinação das sementes dos cultivares estudados foi afetada pelos danos mecânicos. Observa se que nos três cultivares existem diferenças entre os locais onde os danos foram provocados, sendo que as regiões sobre os cotilédones esquerdo e direito diferiram estatisticamente dos demais locais, observando-se maiores percentagens de plântulas normais. Por outro lado, não houve diferenças significativas entre os demais locais onde os danos foram provocados.

O cultivar IAC-2 foi afetado de maneira drástica, apresentando valores nulos para a maioria dos tratamentos. D a mesma maneira, quando se analisam as médias dos cultivares, observase que 0 cultivar FT-2 foi estatisticamente 
superior aos outros dois cultivares, ao passo que o cultivar FT-10 apresentou superioridade em relação ao cultivar IAC-2.

Tabela 8. Valores médios (\%) de plântulas normais dos três cultivares estudados, avaliadas através do teste de germinação, nos diferentes locais onde os danos foram provocados

\begin{tabular}{lcccc}
\hline \multicolumn{1}{c}{ Local de dano } & FT-2 & $\begin{array}{c}\text { CULTIVAR } \\
\text { FT-10 }\end{array}$ & IAC-2 & Médias do local de \\
& $19 \mathrm{a} \mathrm{C}$ & $12 \mathrm{~b} \mathrm{C}$ & $00 \mathrm{~b} \mathrm{C}$ & $10 \mathrm{C}$ \\
\hline Hilo & $16 \mathrm{a} \mathrm{C}$ & $14 \mathrm{~b} \mathrm{C}$ & $00 \mathrm{c} \mathrm{C}$ & $10 \mathrm{C}$ \\
Oposta ao hilo & $17 \mathrm{a} \mathrm{C}$ & $16 \mathrm{a} \mathrm{C}$ & $00 \mathrm{~b} \mathrm{C}$ & $11 \mathrm{C}$ \\
Plúmula & $19 \mathrm{a} \mathrm{C}$ & $16 \mathrm{a} \mathrm{C}$ & $00 \mathrm{~b} \mathrm{C}$ & $12 \mathrm{C}$ \\
Oposta à plúmula & $32 \mathrm{a} \mathrm{B}$ & $26 \mathrm{~b} \mathrm{~B}$ & $02 \mathrm{c} \mathrm{B}$ & $20 \mathrm{~B}$ \\
Cotilédone esquerdo & $36 \mathrm{a} \mathrm{B}$ & $24 \mathrm{~b} \mathrm{~B}$ & $04 \mathrm{c} \mathrm{B}$ & $21 \mathrm{~B}$ \\
Cotilédone direito & $84 \mathrm{a} \mathrm{A}$ & $78 \mathrm{~b} \mathrm{~A}$ & $77 \mathrm{~b} \mathrm{~A}$ & $80 \mathrm{~A}$ \\
Testemunha & $32 \mathrm{a}$ & $26 \mathrm{~b}$ & 12 c & - \\
\multicolumn{1}{c}{ Médias } & & & & \\
\multicolumn{1}{c}{ CV(\%) } & 9,10 & 8,16 & 6,40 & 10,16 \\
\hline Médias seguidas da mesma letra, minúscula na linha e maiúscula na coluna, não diferem
\end{tabular}
entre si pelo teste de Tukey a $5 \%$ de probabilidade

A análise referente à porcentagem de plântulas anormais (Tabela 9), permite verificar diferenças significativas entre os locais de danos dentro dos cultivares FT-2 e FT-10 e comportamento semelhante dentro do cultivar IAC-2.

Para a análise das médias dos locais de danos, foi verificado que as sementes œm dano na região oposta ao hilo apresentou maior percentagem de plântulas anormais em relação aos danos provocados nos outros locais (Tabela 9).

Q uando a análise foi realizada para as médias dos cultivares, verificaramse diferenças significativas entre des; assim o cultivar IAC-2 apresentou maior porcentagem de plântulas anormais, seguidas do cultivar FT-2 e FT-10. 
Tabela 9. Valores médios (\%) de plântulas anormais dos três cultivares estudados, avaliadas através do teste de germinação, nos diferentes bcais onde os danos foram provocados

\begin{tabular}{llccc}
\hline \multicolumn{1}{c}{ Local de dano } & CULTIVAR & & Médias de local de \\
& FT -2 & FT-10 & IAC-2 & dano \\
\hline Hilo & $64 \mathrm{~b} \mathrm{~B}$ & $24 \mathrm{c} \mathrm{B}$ & $96 \mathrm{a} \mathrm{A}$ & $60 \mathrm{C}$ \\
Oposta ao hilo & $78 \mathrm{~b} \mathrm{~A}$ & $48 \mathrm{c} \mathrm{A}$ & $96 \mathrm{a} \mathrm{A}$ & $75 \mathrm{~A}$ \\
Plúmula & $61 \mathrm{c} \mathrm{BC}$ & $49 \mathrm{~b} \mathrm{~A}$ & $94 \mathrm{a} \mathrm{A}$ & $67 \mathrm{BC}$ \\
Oposta à plúmula & $63 \mathrm{~b} \mathrm{~B}$ & $34 \mathrm{c} \mathrm{B}$ & $90 \mathrm{a} \mathrm{A}$ & $64 \mathrm{BC}$ \\
Cotilédone esquerdo & $66 \mathrm{~b} \mathrm{~B}$ & $52 \mathrm{c} \mathrm{A}$ & $92 \mathrm{a} \mathrm{A}$ & $70 \mathrm{~B}$ \\
Cotilédone direito & $63 \mathrm{~b} \mathrm{~B}$ & $50 \mathrm{c} \mathrm{A}$ & $92 \mathrm{a} \mathrm{A}$ & $69 \mathrm{~B}$ \\
Testemunha & $04 \mathrm{c} \mathrm{C}$ & $13 \mathrm{~b} \mathrm{C}$ & $22 \mathrm{a} \mathrm{B}$ & $13 \mathrm{D}$ \\
\multicolumn{1}{c}{ Médias } & $57 \mathrm{~b}$ & $39 \mathrm{c}$ & $83 \mathrm{a}$ & - \\
\multicolumn{1}{c}{ CV $(\%)$} & 7,12 & 7,42 & 4,82 & 7,86 \\
\hline
\end{tabular}

Médias seguidas da mesma letra, minúscula na linha e maiúscula na coluna, não diferem entre si pelo teste de Tukey a $5 \%$ de probabilidade

Nos dados apresentados para percentagem de sementes mortas (Tabela 10), para o cultivar FT-2, é possível verificar que houve diferenças significativas entre os locais de dano, sendo que as sementes com danos no hilo e na plúmula apresentaram maiores índices de sementes mortas. Por outro lado, no cultivar FT-10 as sementes com danos no hilo, foram as que tiveram maior porcentagens de sementes mortas. Já no cultivar IAC-2, as maiores porcentagens de sementes mortas foram encontradas na região oposta à plúmula.

Para as médias de local de dano das sementes (Tabela 10), aquele provocado no hilo, na plúmula e na região oposta à plúmula apresentaram maior número de sementes mortas; talvez a maior incidência de sementes mortas nesses locais de danos tenha sido em função, nos primeiro e segundo casos devido à incidência direta do danificador mecânico (pêndulo) sobre o local onde está situado o eixo embrionário e, no terceiro (região oposta à plúmula), devido ao contato do eixo embrionário com o alvéolo do disco quando foi provocado 0 
dano. As menores porcentagens de sementes mortas foram obtidas, além da testemunha, nos locais onde os danos foram provocados sobre os cotilédones esquerdo e direito, devido ao fato do dano não ter atingido diretamente as partes vitais do eixo embrionário e também, pelo fato do dano não ter sido tão drástico a ponto de afetar a região de transferência de nutrientes dos cotilédones para 0 eixo embrionário.

Quando são analisadas as médias gerais dos cultivares, observa se maior porcentagem de sementes mortas para o cultivar FT-10 em relação aos outros dois e do cultivar FT-2 em relação ao cultivar IAC-2.

Tabela 10. Valores médios (\%) de sementes mortas dos três cultivares estudados, avaliadas através do teste de germinação, nos diferentes locais onde os danos foram provocados

\begin{tabular}{lcccc}
\hline \multicolumn{1}{c}{ Local de dano } & FT-2 & $\begin{array}{c}\text { CULTIVAR } \\
\text { FT-10 }\end{array}$ & IAC-2 & $\begin{array}{c}\text { Médias de local de } \\
\text { dano }\end{array}$ \\
\hline Hilo & $18 \mathrm{~b} \mathrm{C}$ & $74 \mathrm{c} \mathrm{D}$ & $02 \mathrm{a} \mathrm{A}$ & $22 \mathrm{C}$ \\
Oposta ao hilo & 06 a A & $40 \mathrm{~b} \mathrm{C}$ & $04 \mathrm{a} \mathrm{B}$ & $17 \mathrm{~B}$ \\
Plúmula & $22 \mathrm{~b} \mathrm{C}$ & $38 \mathrm{c} \mathrm{C}$ & $06 \mathrm{a} \mathrm{B}$ & $20 \mathrm{BC}$ \\
Oposta à plúmula & $16 \mathrm{~b} \mathrm{~B}$ & $50 \mathrm{c} \mathrm{C}$ & $10 \mathrm{a} \mathrm{C}$ & $27 \mathrm{C}$ \\
Cotilédone esquerdo & $02 \mathrm{a} \mathrm{A}$ & $22 \mathrm{~b} \mathrm{~B}$ & $04 \mathrm{a} \mathrm{B}$ & $10 \mathrm{~A}$ \\
Cotilédone direito & $02 \mathrm{a} \mathrm{A}$ & $24 \mathrm{~b} \mathrm{~B}$ & $04 \mathrm{a} \mathrm{B}$ & $12 \mathrm{~A}$ \\
Testemunha & $10 \mathrm{~b} \mathrm{~B}$ & $09 \mathrm{a} \mathrm{A}$ & $06 \mathrm{a} \mathrm{B}$ & $10 \mathrm{~A}$ \\
\multicolumn{1}{c}{ Médias } & $11 \mathrm{~b}$ & $35 \mathrm{c}$ & $04 \mathrm{a}$ & - \\
\multicolumn{1}{c}{ CV (\%) } & & & & \\
\hline
\end{tabular}

Médias seguidas da mesma letra, minúscula na linha e maiúscula na coluna, não diferem entre si pelo teste de Tukey a 5\% de probabilidade

O teste do pêndulo foi um método muito drástico na danificação das sementes dos três cultivares, sendo que tal fato pode ser observado quando se compara às porcentagens de plântulas normais da testemunha com os dos demais tratamentos (Tabela 8). 
Q uando os diferentes locais de danos nas sementes foram analisados, foi evidenciado que os danos provocados sobre os cotilédones esquerdo e direito, se mostraram mais resistentes quando comparados com os outros locais de dano, proporcionando as maiores porcentagens de plântulas normais (Tabela 8).

No presente trabalho observou-se que o cultivar FT-2 se comportou como o mais resistente ao dano mecânico, seguido do cultivar FT-10; 0 cultivar IAC-2 mostrou-se menos resistente. De acordo com os resultados obtidos no teste de germinação, pode-se classificar FT-2 como resistente, 0 FT-10 como medianamente resistente e o IAC-2 como menos resistente. Estes resultados concordam com a classificação feita por Alvarez (1994).

As figuras apresentadas a seguir ilustram exemplos relativos aos três cultivares estudados. Na semente 48 do cultivar FT-10 (Figura 4) na qual 0 dano foi provocado na região do hilo, foram constatados danos mecânicos externos severos (nota 3), apresentando o tegumento rachado e levantado (Figura 4A). A imagem de raios-X (Figura 4B), com nota 3/3 (danos severos no eixo embrionário e nos cotilédones), por sua vez, acusou fraturas nos cotilédones e no eixo embrionário, entre a plúmula e o hipocótilo e na parte intermediária do hipocótilo, resultando em uma plântula anormal, com o hipocótilo desenvolvido, mas sem a raiz primária (Figura 4C). 

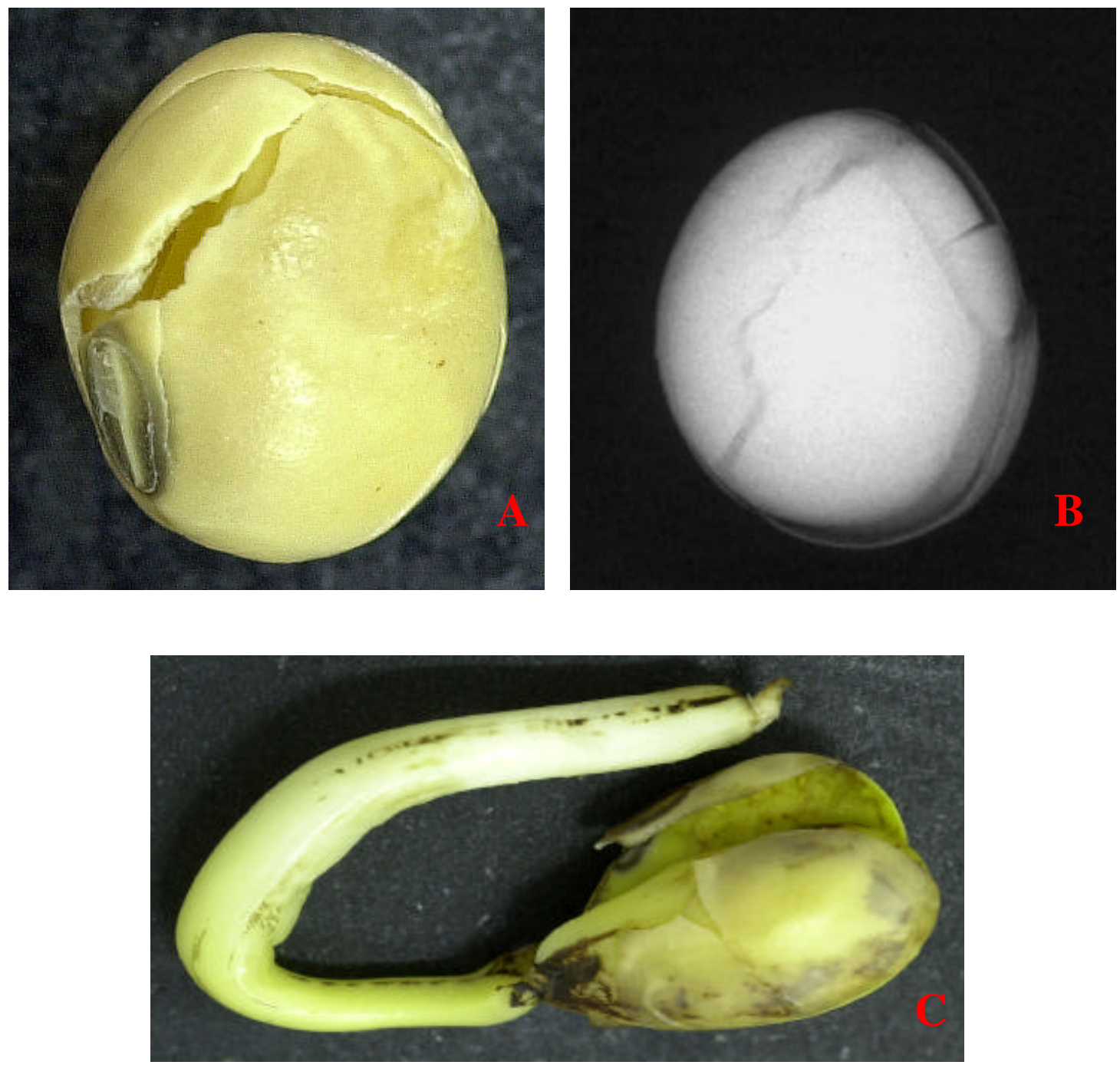

Figura 4 - Cultivar FT-10, semente número 48 (dano provocado no hilo): imagem externa (A); radiografia (B) e plântula anormal (C) 
Na Figura 5 podese observar a semente 36 do cultivar FT-2, na qual 0 dano mecânico foi provocado na região oposta ao hilo, apresentando 0 tegumento trincado, deslocado e levantado (Figura 5A) com nota 3 (dano severo). Na radiografia (Figura 5B), pode-se observar fraturas localizadas entre a plúmula e o hipocótilo e no cilindro central (seccionamento longitudinal), com nota $3 / 2$ na análise radiográfica (dano severo no eixo embrionário e dano não severo nos cotilédones) e, como conseqüência, uma plântula anormal resultante do teste de germinação (Figura 5C).

Na Figura 6, podese observar a semente 83 do cultivar FT-2, na qual o dano mecânico foi provocado na região oposta ao hilo, onde foram constatados danos mecânicos externos no tegumento (Figura 6A), com nota 3 (dano severo). A imagem de raios-X (Figura 6B) acusou dano severo, com notas 3/3 (danos severos na região do eixo embrionário e nos cotilédones), mostrando fratura em toda a área transversal da semente, seccionando os cotilédones e o eixo embrionário. A plântula anormal resultante (Figura 6C), relacionou-se com os danos mecânicos, observados na imagem de raios- $\mathrm{X}$, no eixo embrionário e nos cotilédones.

Na Figura 7, semente 28 do cultivar IAC-2 (o dano foi provocado na região oposta ao hilo), podese observar na análise externa da semente (Figura 7A) um dano severo (nota 3) na forma de amassamento e trinca no cotilédone. A imagem de raios-X (Figura 7B) acusou danos na região dos cotilédones, com nota $1 / 3$ (sem dano na região do eixo embrionário e dano severo no cotilédone), resultando, após o teste de germinação, uma plântula anormal (Figura 7C). Esta figura mostra que, apesar de o dano mecânico ter sido provocado numa região distante do eixo embrionário, este afetou de 
maneira direta 0 desenvolvimento da plântula; provavelmente, houve comprometimento na translocação de nutrientes dos cotilédones para 0 eixo embrionário.
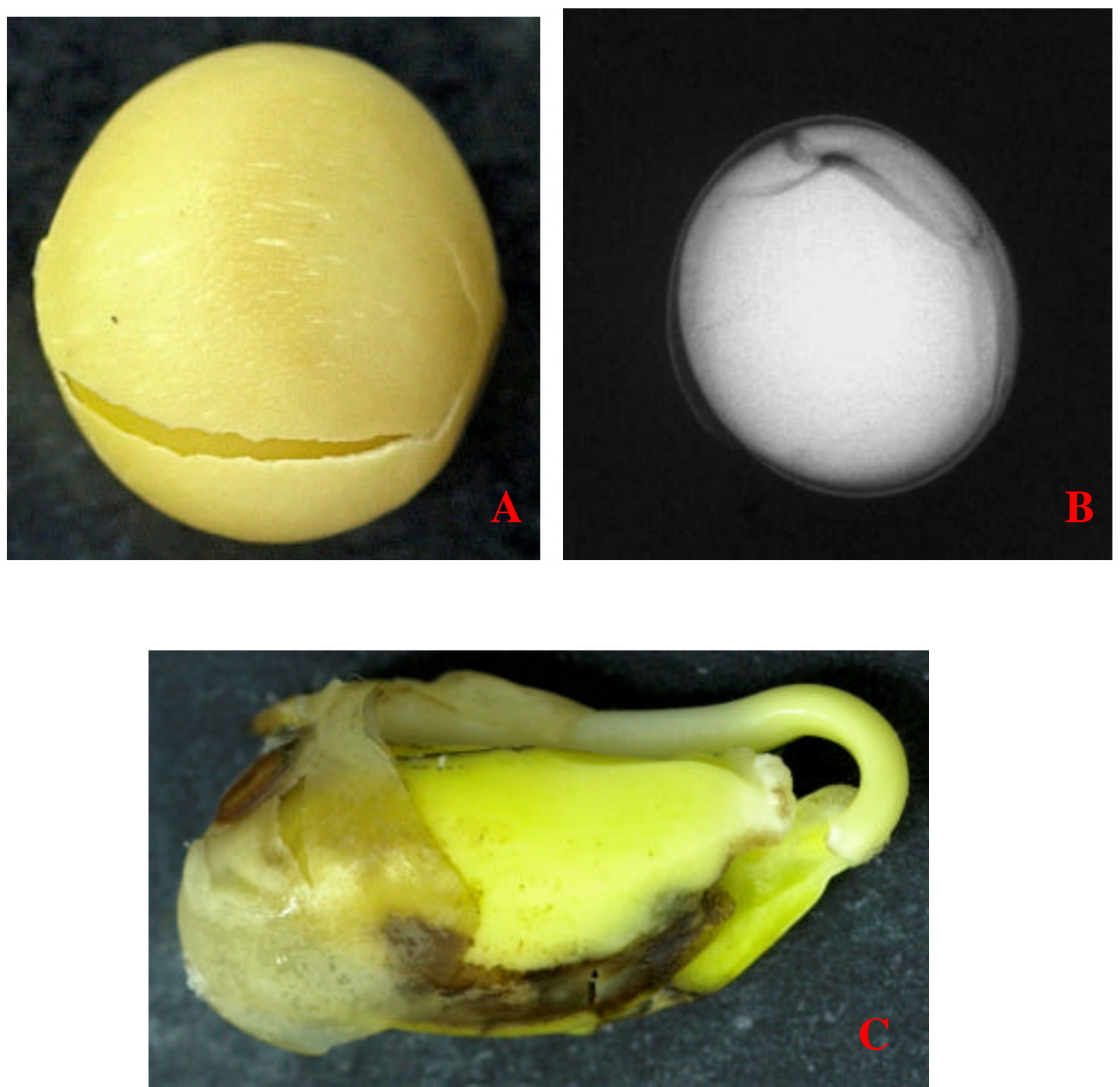

Figura 5 - Cultivar FT-2, semente número 36 (dano provocado na região oposta ao hilo): imagem externa (A); radiografia (B) e plântula anormal (C) 

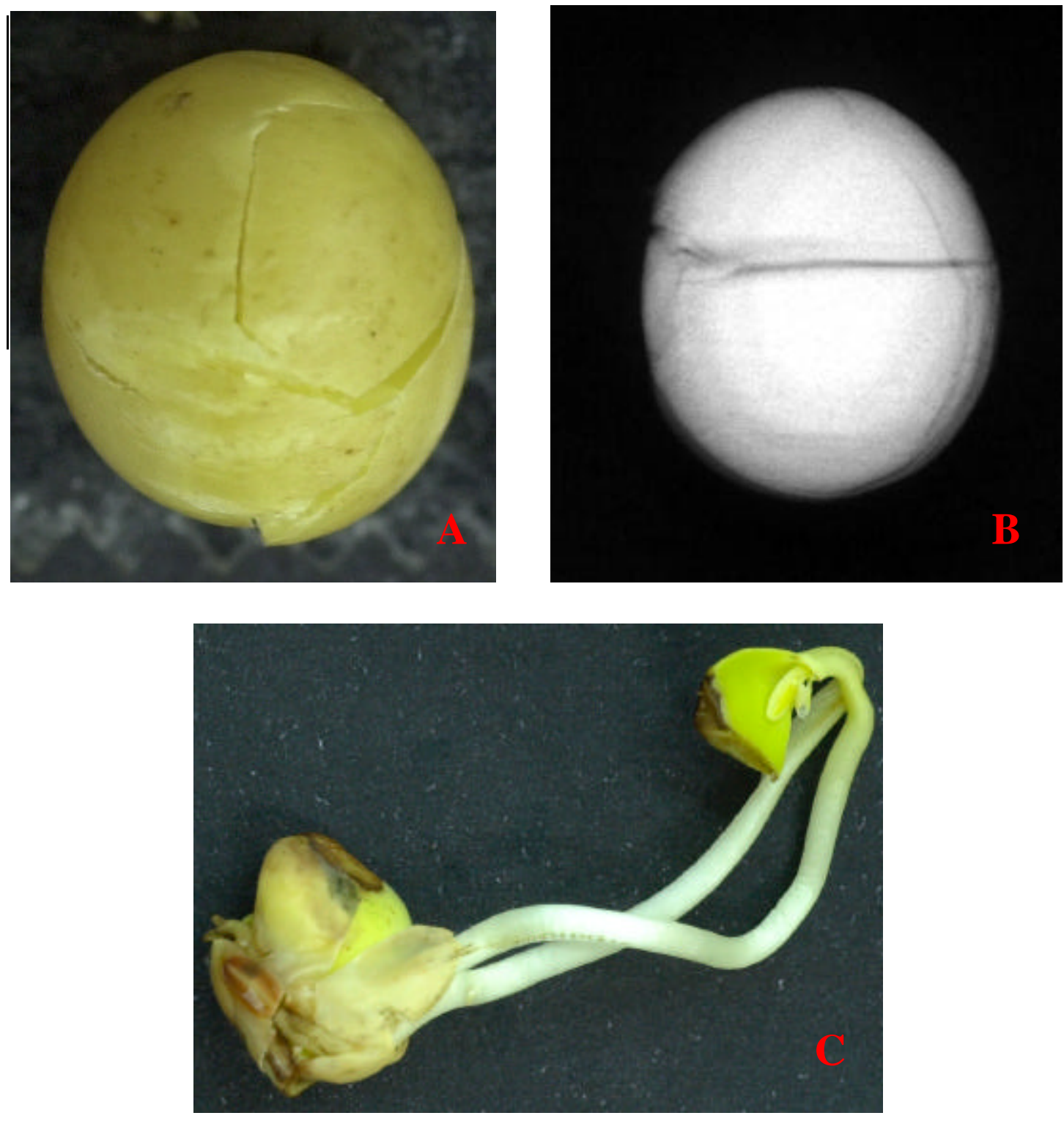

Figura 6 - Cultivar FT-2, semente número 83 (dano provocado na região oposta ao hilo): imagem externa (A); radiografia (B) e plântula anormal (C) 

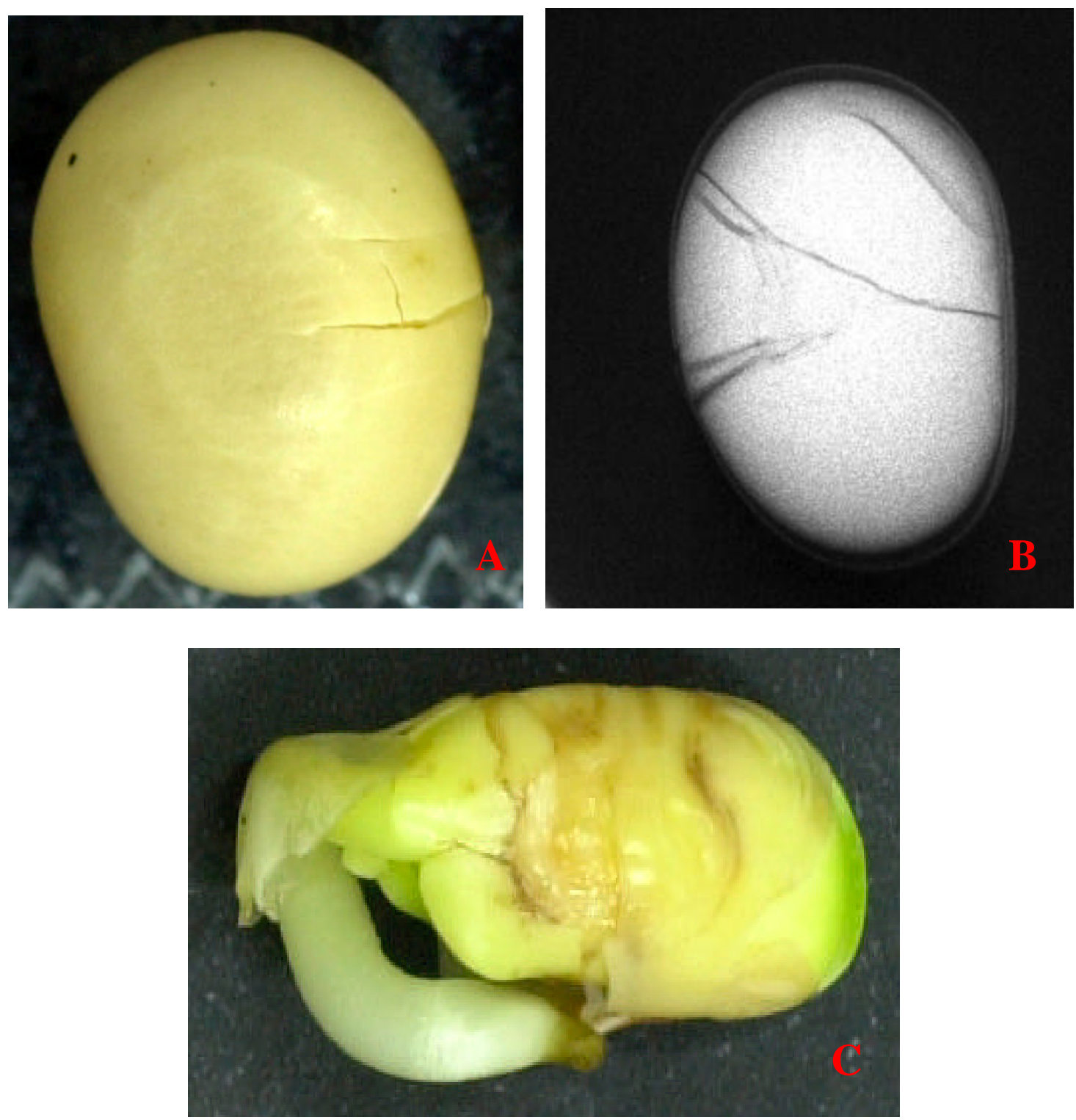

Figura 7 - Cultivar IAC-2, semente número 28 (dano provocado na região oposta ao hilo): imagem externa (A); radiografia (B) e plântula anormal (C) 
Na Figura 8, podese observar a semente 11 do cultivar IAC-2, na qual foi provocado o dano na região da plúmula, a qual apresentou danos mecânicos externos severos (nota 3) na região superior do cotilédone (Figura 8A). Por outro lado, a imagem de raios-X (Figura 8B) acusou danos severos no eixo embrionário e não severos nos cotilédones, com nota $3 / 2$, resultando uma plântula anormal (Figura 8C).

Na semente 34 do cultivar IAC-2 (Figura 9), com o dano mecânico provocado na região oposta à plúmula, foi constatado uma rachadura externa no tegumento (Figura 9A), com nota 2. A análise radiográfica acusou dano severo, com nota 3/ 3 (danos severos no eixo embrionário e nos cotilédones), mostrando as regiões do hipocótilo e a radícula separados (Figura 9B). Neste caso o dano mecânico ocorrido na parte oposta à plúmula se estendeu até o eixo embrionário, resultando uma plântula anormal (Figura 9C).

A semente 67 do cultivar FT-2 (Figura 10), em que o dano foi provocado na região do cotilédone esquerdo, não apresentou dano externo visível (Figura 10A), mas na análise radiográfica observa-se um dano transversal à semente atingindo quase a totalidade do cotilédone (Figura 10B), com nota $3 / 3$ (dano severo nas regiões dos cotilédones e do eixo embrionário) originando, em conseqüência, uma plântula anormal (Figura 10C). Com esta Figura, verifica-se a vantagem do teste de raios-X para detectar danos mecânicos, onde a radiografia mostra os danos internos que não são observados pela analise visual externa (olho nu), concordando com as observações feitas por Cícero et al. (1998), os quais relataram que a análise de imagens, por ser um método não destrutivo, permite comprovar por 
meio de testes de germinação se os danos mecânicos detectados externamente e internamente nas sementes apresentam efeitos sobre a qualidade fisiológica e, assim, ajudar a entender o motivo de uma determinada semente, com danos mecânicos externos e internos aparentemente importantes, originar uma plântula normal.
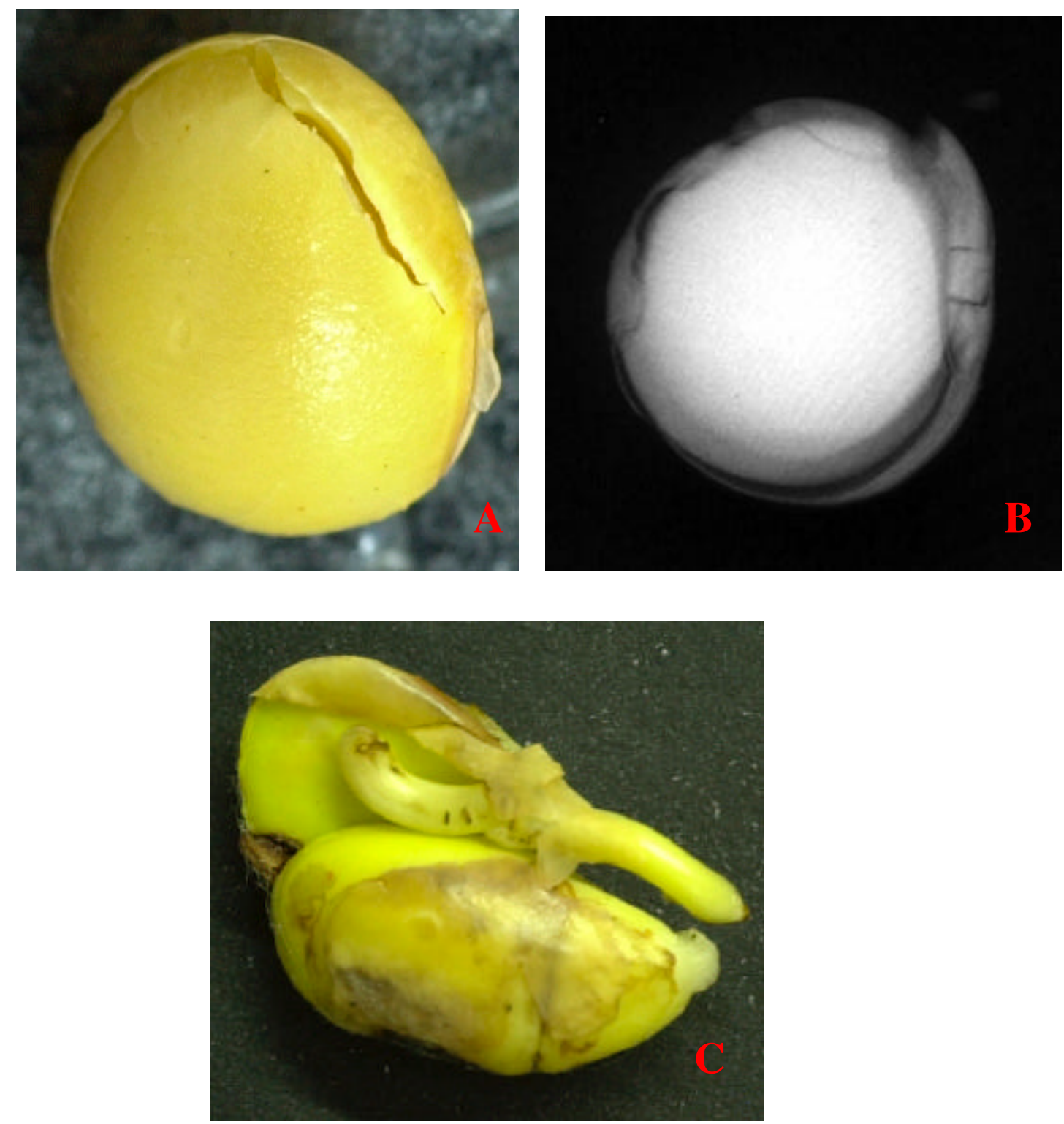

Figura 8 - Cultivar IAC-2, semente número 11 (dano provocado na plúmula): imagem externa (A); radiografia (B) e plântula anormal (C) 

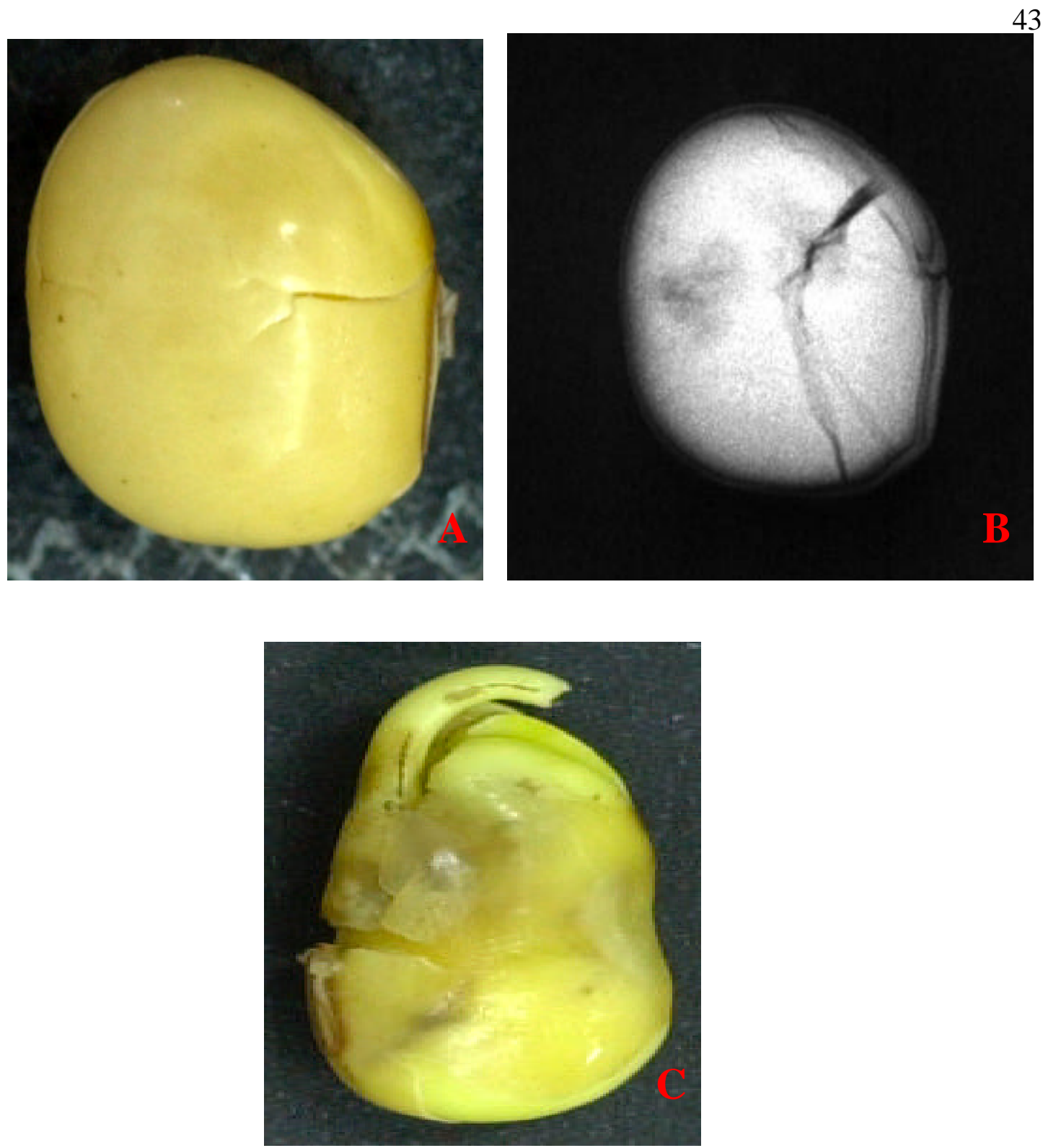

Figura 9 - Cultivar IAC-2, semente número 34 (dano provocado na região oposta à plúmula): imagem externa (A); radiografia (B) e plântula anormal (C) 

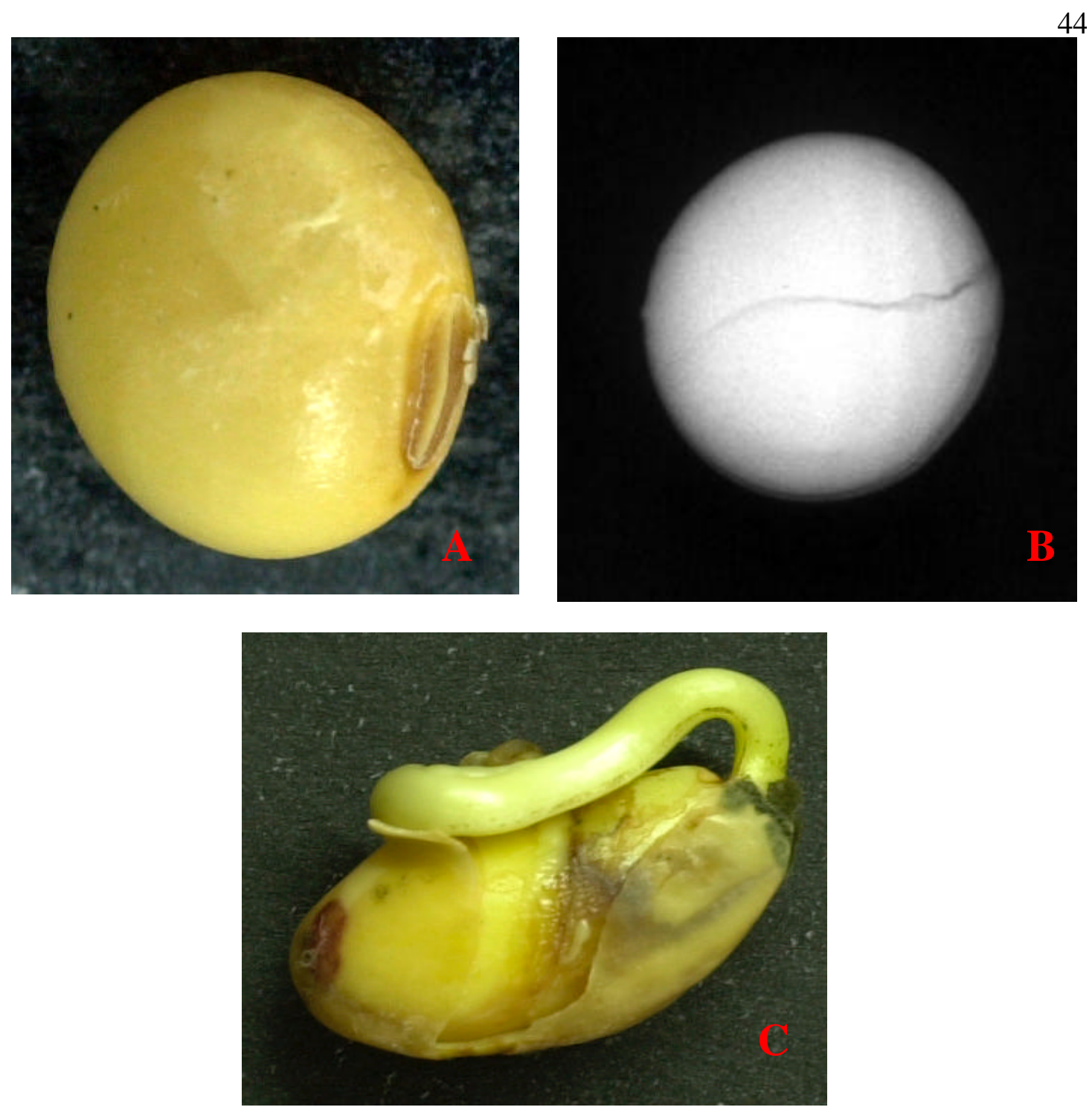

Figura 10 - Cultivar FT-2, semente número 67 (dano provocado no cotilédone esquerdo): imagem externa (A); radiografia (B) e plântula anormal (C)

Na semente 52, do cultivar FT-2 (Figura 11) pode-se observar a semente com o dano provocado na região do cotilédone direito, a qual 
apresenta danos mecânicos externos na forma de rachaduras no tegumento (Figura 11A). A análise radiográfica (Figura 11B) indicou a existência de danos no cotilédone com notas $1 / 3$ (sem dano na região do eixo embrionário e dano severo no cotilédone). Os danos mecânicos detectados próximos ao eixo embrionário parecem ter restringido a translocação de nutrientes necessários para o seu crescimento e, como conseqüência, resultou uma plântula anormal (Figura 11C).

Na Figura 12 está apresentada a semente 16 do cultivar FT-2, a qual não sofreu dano mecânico (testemunha). A imagem externa (Figura 12A) mostra a semente sem nenhum dano (nota 1). A radiografia (Figura 12B) mostra 0 eixo embrionário bem diferenciado com notas $1 / 1$ (sem danos no eixo embrionário e nos cotilédones), resultando em uma plântula normal (Figura 12C).

Na Figura 13, pode-se observar a semente 25, do cultivar FT-10 (testemunha), na qual não foram constatados danos mecânicos externos (Figura 13A), mas a imagem de raios-X (Figura 13B) indicou a existência de rugas na parte oposta ao hilo, constatando-se a presença de dano por umidade. A semente morta constatada no teste de germinação (Figura 13C) relacionou-se com o dano por umidade, observado análise radiográfica. O bservações feitas por França Neto et al. (1999) indicam que sementes com deterioração por umidade apresentam rugas características nos cotilédones, na região oposta ao hilo, ou sobre o eixo embrionário. 

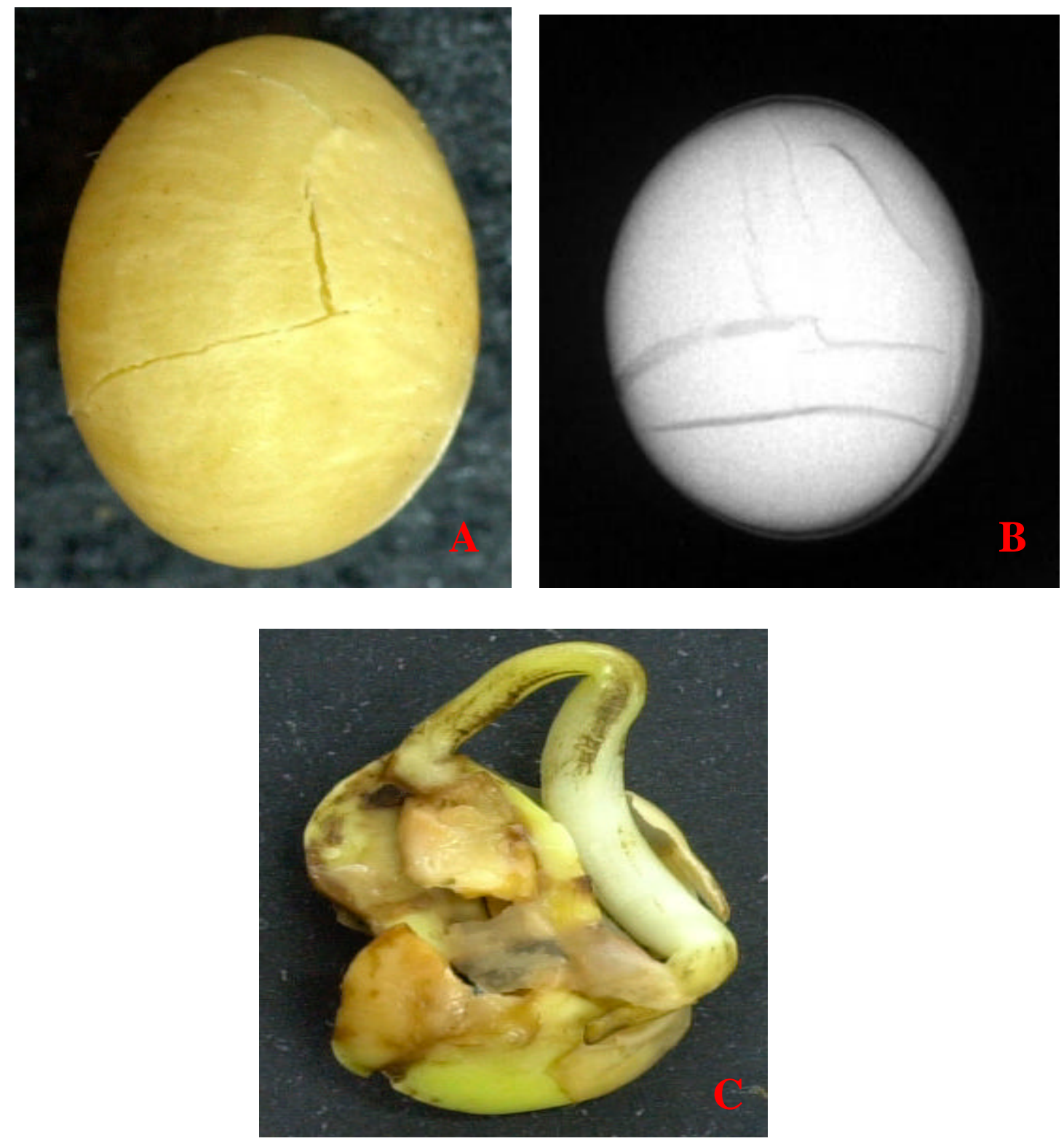

Figura 11 - Cultivar FT-2, semente número 52 (dano provocado no cotilédone direito): imagem externa (A); radiografia (B) e plântula anormal (C) 

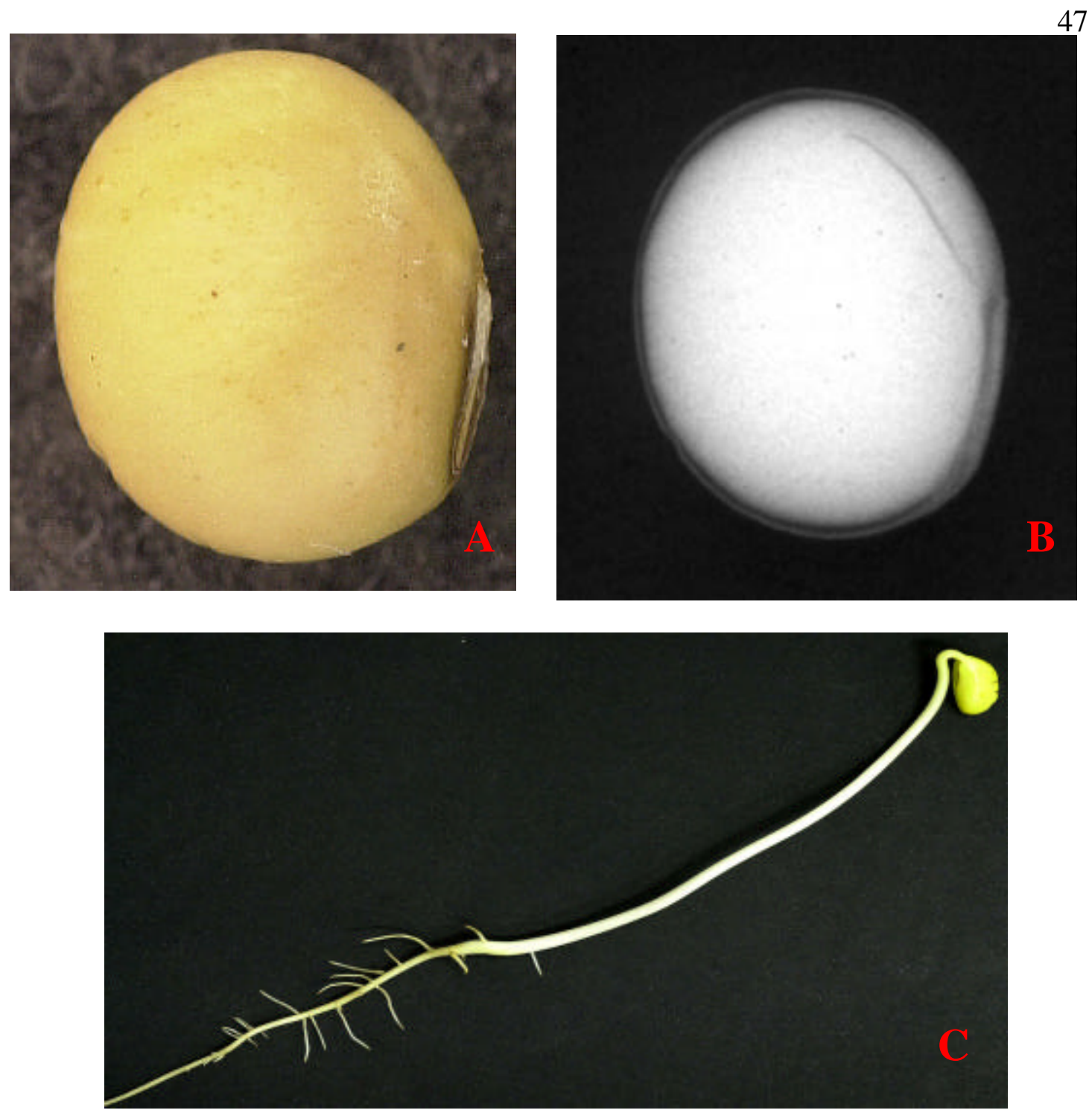

Figura 12 - Cultivar FT-2, semente número 16 (testemunha): imagem externa (A); radiografia (B) e plântula normal (C) 

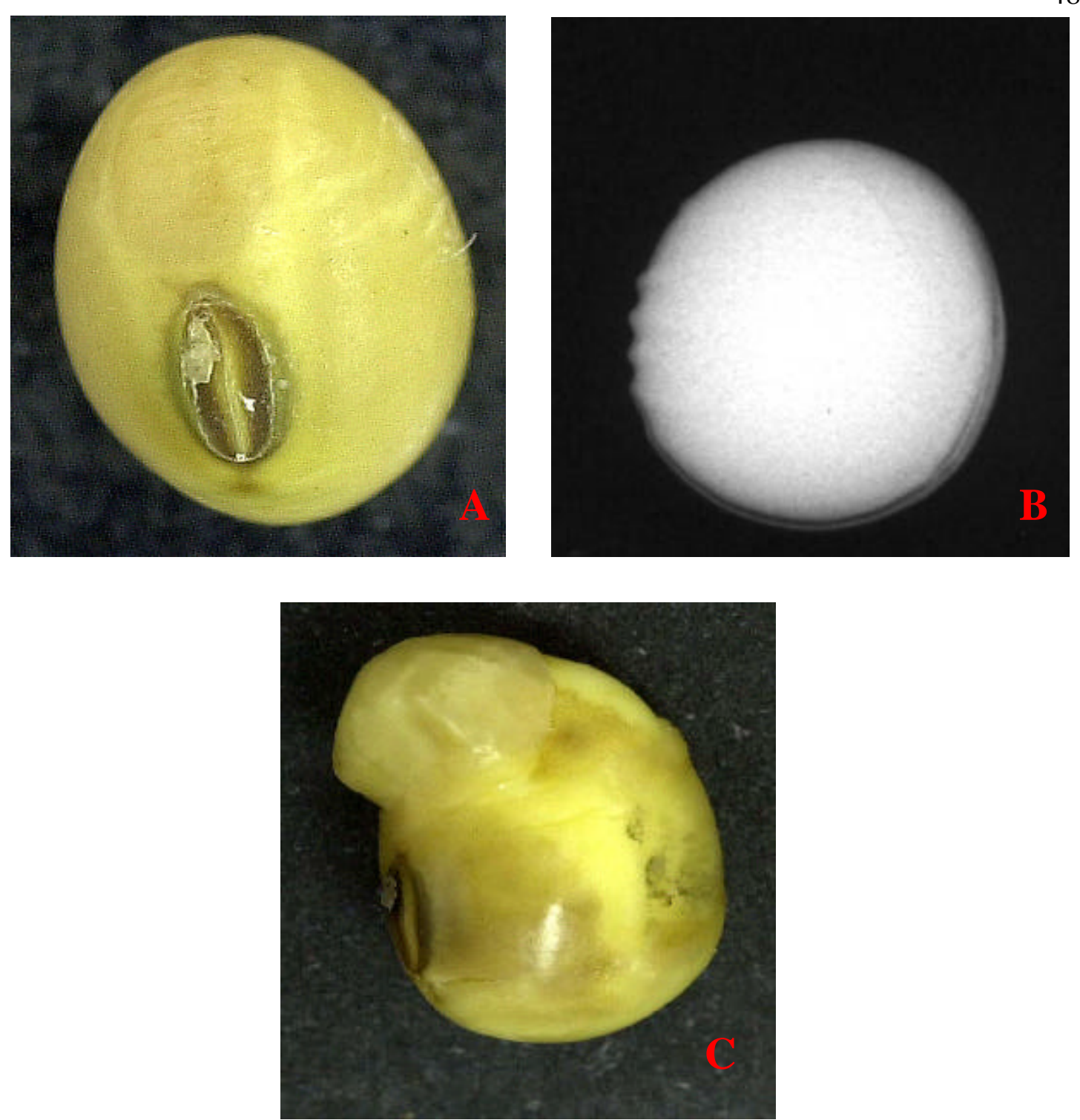

Figura 13 - Cultivar FT-10, semente número 25 (testemunha): imagem externa (A); radiografia (B) e semente morta (C) 
Na Figura 14 podese observar a semente 17 do cultivar IAC-2, com 0 dano mecânico provocado na região oposta ao hilo, onde foi constatado dano mecânico externo na sutura cotiledonar (Figura 14A). Entretanto, a imagem de raios-X não revelou dano mecânico interno; porém, acusou danos internos produzidos por percevejos (Figura 14B). Como conseqüência, houve morte da semente (Figura 14C). 0 ataque de percevejo proporciona lesões circulares características, muitas vezes enrugadas e profundas, podendo ocorrer leões múltiplas numa única semente (França Neto et al., 1999).

D esta maneira a radiografia permite observar sementes com danos mecânicos, danos por umidade e danos por percevejo, como mostrados nas figuras anteriores. A literatura também indica que a radiografia das sementes permite a visualização de injúrias mecânicas, danos por insetos e decorrentes de outros fatores adversos de pré e pós-colheita, na forma de rachaduras ou fraturas (ISTA, 1993; Poulsen et al., 1998).

Assim, a utilização da análise de imagens para a determinação de danos mecânicos, danos por umidade e danos por percevejo em sementes de soja, mostra-se como uma boa alternativa em relação a outros métodos utilizados para o mesmo fim, com a vantagem de se poder comprovar os efeitos dos danos, por meio de testes fisiológicos, pois trata-se de um método não destrutivo. 

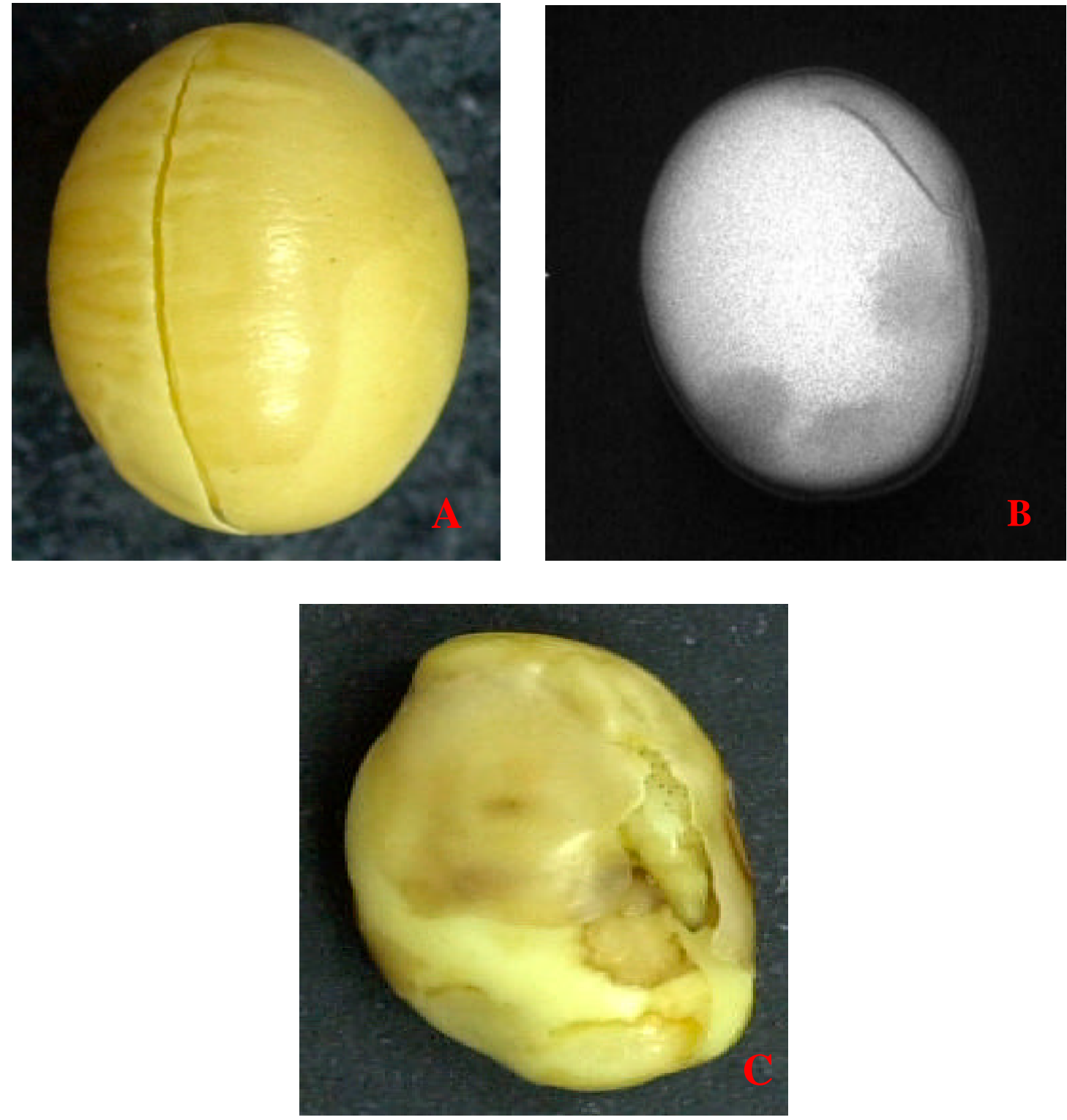

Figura 14 - Cultivar IAC-2, semente número 17 (dano provocado na região oposta ao hilo): imagem externa (A); radiografia (B) e semente morta (C) 


\subsection{Teste de tetrazólio}

$\mathrm{Na}$ Tabela 11, encontram-se os dados referentes à viabilidade, vigor e danos mecânicos das sementes depois de terem sido submetidos ao teste do pêndulo. No cultivar FT-2 a viabilidade foi afetada de maneira drástica, sendo que as sementes com dano provocado na região do hilo foram as mais prejudicadas quando comparadas com a testemunha e, também, com as sementes com danos provocados em outros locais.

O cultivar FT-10 também teve suas sementes muito afetadas pelos danos mecânicos, sendo que as menores porcentagens de viabilidade foram verificadas nas sementes com danos no hilo e na plúmula. Por outro lado, 0 local de dano sobre os cotilédones esquerdo e direito não foram prejudiciais às sementes.

O cultivar IAC-2 teve suas sementes, também, seriamente afetadas em todos os locais onde os danos foram provocados, sendo que a região de dano no hilo foi a que provocou maior queda na viabilidade das sementes.

Com relação ao vigor (Tabela 11), observa-se, para os três cultivares, que as sementes que sofreram danos mecânicos, independentemente dos locais apresentaram vigor mais baixo em relação às sementes da testemunha. Para o cultivar FT-2, as regiões danificadas, pelo teste do pêndulo, no hilo, na parte oposta ao hilo e na plúmula foram os que apresentaram sementes com mais baixo vigor em relação aos demais locais onde os danos foram provocados. No cultivar FT-10, as sementes com a região danificada no hilo, na região oposta ao hilo, na plúmula e região oposta à plúmula apresentaram vigor mais baixo do que 0 das sementes com danos provocados nos cotilédones. 
Para 0 cultivar IAC-2, os índices de vigor foram os mais baixos, apresentando, inclusive, valores nulos quando as regiões afetadas foram 0 hilo e a região oposta ao hilo.

De maneira geral, a viabilidade e 0 vigor dos três cultivares foram afetados pelo danos mecânicos, sendo que a queda mais drástica na qualidade das sementes foi verificada quando o dano mecânico foi provocado na região do hilo, na região oposta ao hilo e na plúmula. Por outro lado, efeitos menos prejudiciais foram obtidos quando o dano foi provocado sobre os cotilédones esquerdo e direito.

O cultivar FT-2 apresentou, em geral, melhor nível de viabilidade e de vigor do que os cultivares FT-10 e IAC-2, depois de terem sido submetidos ao teste do pêndulo. Para o cultivar IAC-2, a redução da viabilidade e do vigor foram mais acentuadas, destacando-se nesta comparação a maior resistência do cultivar FT-2 ao dano mecânico em relação ao cultivar IAC-2, que apresentam, respectivamente, alto e baixo percentuais de lignina no tegumento de suas sementes (Alvarez, 1994).

Para os valores médios de níveis de danos mecânicos leves, avaliados pelo teste do tetrazólio (Tabela 11), verifica-se que os valores mais altos deste tipo de dano ocorreram nas regiões laterais dos cotilédones, para os três cultivares. No cultivar IAC-2 a porcentagem de danos mecânicos leves foi mais acentuada que nos outros dois cultivares.

Com relação aos níveis de danos mecânicos severos apresentados na Tabela 11, verifica-se que houve alta incidência desta categoria de dano. 0 cultivar IAC-2 apresentou, em valores absolutos, maior incidência de danos do que os outros dois cultivares, o que pode ter contribuído para que esse cultivar tivesse menor nível de vigor. Este comportamento diferencial entre 
cultivares, fundamenta-se na variabilidade existente nas sementes de soja para qualidade e suscetibilidade da semente ao dano mecânico (Krzyzanowski et al., 1989).

Tabela 11. Valores médios de viabilidade, vigor e danos mecânicos (D M) em sementes de três cultivares de soja, avaliadas pelo teste de tetrazólio, depois das sementes terem sido submetidas ao teste do pêndulo

\begin{tabular}{|c|c|c|c|c|c|c|}
\hline $\begin{array}{c}\text { Cultiva } \\
\mathrm{r}\end{array}$ & Local de D ano & $\begin{array}{c}\text { Viabilidad } \\
\mathrm{e} \\
(\%)\end{array}$ & $\begin{array}{l}\text { Vigor } \\
(\%)\end{array}$ & $\begin{array}{c}\text { D M Leve } \\
(\%)\end{array}$ & $\begin{array}{c}\text { D M Severo } \\
(\%)\end{array}$ & $\begin{array}{l}\text { DM Muito } \\
\text { Severo (\%) }\end{array}$ \\
\hline \multirow{7}{*}{ FT-2 } & Hilo & $29 \mathrm{~d}$ & $14 \mathrm{e}$ & $12 \mathrm{c}$ & $76 a$ & $72 \mathrm{c}$ \\
\hline & O posta ao hilo & $74 \mathrm{~b}$ & $13 e$ & $16 \mathrm{~b}$ & $42 \mathrm{e}$ & $83 a$ \\
\hline & Plúmula & $70 \mathrm{~b} \mathrm{c}$ & $16 \mathrm{e}$ & $16 \mathrm{~b}$ & $68 \mathrm{~b}$ & $78 \mathrm{~b}$ \\
\hline & O posta à plúmula & $60 c$ & $22 \mathrm{~d}$ & $18 \mathrm{~b}$ & $48 d$ & $74 \mathrm{c}$ \\
\hline & Cotilédone esquerdo & $56 \mathrm{~cd}$ & $28 \mathrm{c}$ & $24 \mathrm{a}$ & $52 \mathrm{c}$ & $63 \mathrm{e}$ \\
\hline & Cotilédone direito & $68 \mathrm{bc}$ & $34 \mathrm{~b}$ & $28 \mathrm{a}$ & $52 \mathrm{c}$ & $68 \mathrm{~d}$ \\
\hline & Testemunha & $84 \mathrm{a}$ & $81 \mathrm{a}$ & - & - & - \\
\hline \multirow{7}{*}{ FT-10 } & Hilo & $22 \mathrm{~d}$ & $09 \mathrm{e}$ & $08 \mathrm{~d}$ & $78 a$ & $90 \mathrm{a}$ \\
\hline & O posta ao hilo & $55 \mathrm{~b}$ & $15 d$ & $15 \mathrm{c}$ & $49 \mathrm{c}$ & $89 a$ \\
\hline & Plúmula & $26 \mathrm{~d}$ & $12 \mathrm{~d}$ & $14 \mathrm{c}$ & $76 a$ & $92 \mathrm{a}$ \\
\hline & O posta à plúmula & $44 \mathrm{C}$ & $14 \mathrm{~d}$ & $15 \mathrm{c}$ & $55 \mathrm{~b}$ & $86 \mathrm{~b}$ \\
\hline & Cotilédone esquerdo & $85 a$ & $42 \mathrm{~b}$ & $44 \mathrm{a}$ & $14 \mathrm{~d}$ & $52 \mathrm{~d}$ \\
\hline & Cotilédone direito & $84 \mathrm{a}$ & $34 \mathrm{c}$ & $32 \mathrm{~b}$ & $20 \mathrm{~d}$ & $60 \mathrm{c}$ \\
\hline & Testemunha & $85 \mathrm{a}$ & $79 a$ & - & - & - \\
\hline \multirow{7}{*}{ IAC-2 } & Hilo & $10 \mathrm{~d}$ & $00 \mathrm{~d}$ & $31 \mathrm{~b}$ & $88 \mathrm{ab}$ & $96 a$ \\
\hline & O posta ao hilo & $18 \mathrm{c}$ & $00 \mathrm{~d}$ & $28 \mathrm{c}$ & $85 \mathrm{~b}$ & $98 \mathrm{a}$ \\
\hline & Plúmula & $20 c$ & $02 \mathrm{c}$ & $33 \mathrm{~b}$ & $90 \mathrm{a}$ & $92 \mathrm{~b}$ \\
\hline & O posta à plúmula & $26 \mathrm{~b}$ & $02 \mathrm{c}$ & $31 \mathrm{c}$ & $86 \mathrm{~b}$ & $90 \mathrm{bc}$ \\
\hline & Cotilédone esquerdo & $26 \mathrm{~b}$ & $06 \mathrm{~b}$ & $36 \mathrm{a}$ & $88 \mathrm{ab}$ & $92 \mathrm{~b}$ \\
\hline & Cotilédone direito & $28 \mathrm{~b}$ & $08 \mathrm{~b}$ & $36 a$ & $80 \mathrm{c}$ & $88 \mathrm{c}$ \\
\hline & Testemunha & $76 \mathrm{a}$ & $66 a$ & - & - & - \\
\hline CV (\%) & & 5,93 & 9,98 & 7,33 & 5,34 & 5,03 \\
\hline
\end{tabular}


Para os danos mecânicos muito severos, observou-se que quando os danos foram provocados no hilo, na região oposta ao hilo e na plúmula, houve maior porcentagem de sementes danificadas, enquanto que os danos provocados sobre os cotilédones esquerdo e direito proporcionaram menores porcentagens de danificações muito severas.

Analisando as médias dos cultivares (Tabela 12), verifica-se que 0 cultivar IAC-2 foi o mais prejudicado na viabilidade e no vigor e o que mais apresentou danos mecânicos leves, severos e muito severos. 0 cultivar FT-2 apresentou, em geral, os menores índices de danos em relação aos FT-10 e IAC-2. Isto pode ser fundamentado na variabilidade genética existente na espécie quanto à resistência a esse fator, como já demonstrado para diversos genótipos por Agrawal \& Menon (1974); Krzyzanowski et al. (1989) e Carbonell \& Krzyzanowski (1995).

Tabela 12. Valores médios de viabilidade, vigor e danos mecânicos, avaliados pelo teste de tetrazólio, nas sementes dos três cultivares estudados

\begin{tabular}{cccccc}
\hline Cultivar & $\begin{array}{c}\text { Viabilidade } \\
(\%)\end{array}$ & $\begin{array}{c}\text { Vigor } \\
(\%)\end{array}$ & $\begin{array}{c}\text { D M Leve } \\
(\%)\end{array}$ & $\begin{array}{c}\text { D M Severo } \\
(\%)\end{array}$ & $\begin{array}{c}\text { D M Muito Severo } \\
(\%)\end{array}$ \\
\hline FT-2 & $63 \mathrm{a}$ & $29 \mathrm{a}$ & $19 \mathrm{~b}$ & $56 \mathrm{~b}$ & $72 \mathrm{c}$ \\
FT-10 & $62 \mathrm{a}$ & $27 \mathrm{a}$ & $20 \mathrm{~b}$ & $48 \mathrm{c}$ & $80 \mathrm{~b}$ \\
IAC-2 & $25 \mathrm{~b}$ & $07 \mathrm{~b}$ & $32 \mathrm{a}$ & $86 \mathrm{a}$ & $93 \mathrm{a}$ \\
& & & & & 5,34 \\
CV (\%) & 5,93 & 9,98 & 7,33 & 5,03 \\
\hline
\end{tabular}

Médias seguidas da mesma letra, na coluna, não diferem entre si pelo teste de Tukey a 5\% de probabilidade

A Figura 15 ilustra exemplo relativo aos três cultivares estudados, através das imagens fotográficas das sementes de soja sem danos mecânicos (testemunha) provenientes do teste de tetrazólio, classificadas como altamente vigorosas e viáveis, baseadas na classificação de França Neto et al. 
(1999). Pode-se observar 0 aspecto geral das estruturas das sementes, com coloração rosa claro em toda extensão do eixo embrionário e nos cotilédones, com os tecidos firmes e túrgidos, sem apresentar lesões visíveis.
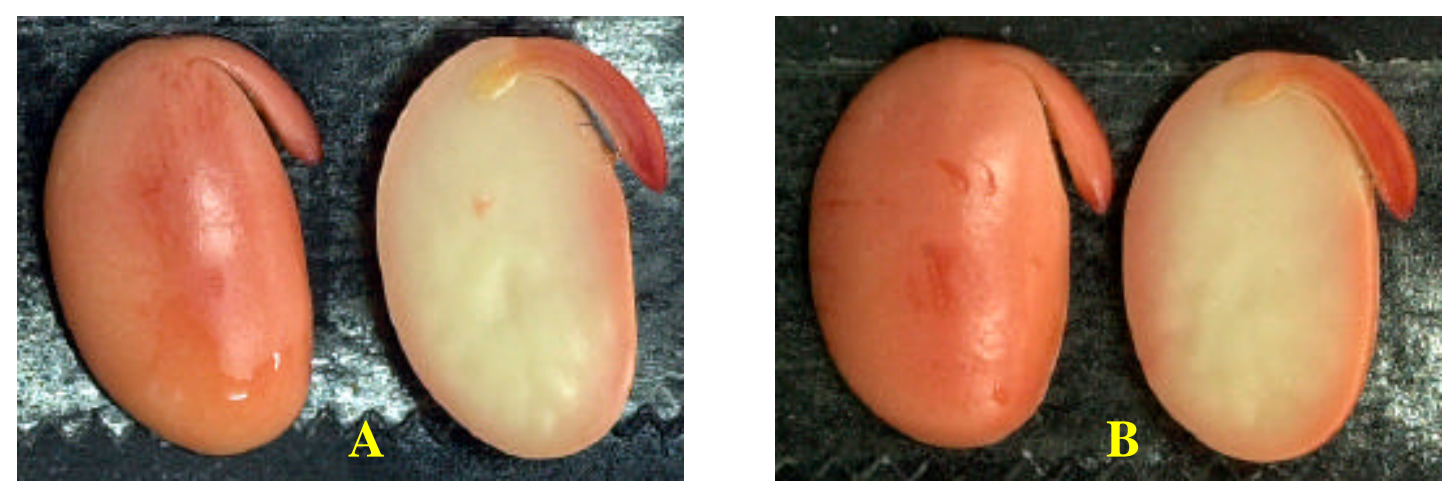

Figura 15 - Teste de tetrazólio: sementes do cultivar FT-2 (A e B), sem dano mecânico (testemunha)

Na Figura 16 são apresentadas sementes do cultivar FT-2. Na Figura $16 \mathrm{~A}$, semente 11 , observa-se a semente com o dano provocado na região do hilo, podendo-se verificar parte do eixo embrionário seccionado e com uma trinca no cotilédone, sendo uma semente não viável, segundo França neto et al. (1999).

Na semente 25, Figura 16B, pode-se observar a semente com o dano provocado na parte oposta ao hilo. A distribuição do dano vai da região oposta ao hilo até a outra extremidade do cotilédone e se manifesta na forma de uma trinca interna, sendo considerada uma semente não viável.

A semente 56 (Figura 16C) refere-se ao dano provocado na plúmula. Nesta, pode-se observar o eixo embrionário incompleto (seccionado), sendo classificada como semente não viável.

Na Figura 16D, semente 42, na qual o dano foi provocado na parte oposta à plúmula, pode-se observar que 0 impacto fez com que o dano se 
dispersasse da parte oposta à plúmula (parte inferior da semente) em direção à plúmula, chegando a atingi-la, sendo classificada como semente não viável.

O utra região de dano provocado pelo teste do pêndulo foi sobre 0 cotilédone esquerdo, conforme mostra a Figura 16E, na semente 67; o dano apenas é observado como uma pequena rachadura interna e a semente é classificada como de alto vigor. A Figura 16F (semente 31) mostra o dano provocado, desta vez, sobre o cotilédone direito, apresentando a mesma forma de dispersão do impacto na semente do que na figura anterior, sem comprometer as partes vitais do eixo embrionário (vigor médio).

Na Figura 17 estão apresentadas as sementes do cultivar FT-10. Na semente 38, com dano provocado na região do hilo (Figura 17A), pode-se observar que o dano se distribui desde a região do eixo embrionário até a parte oposta do hilo, comprometendo a viabilidade da semente.

Na semente 12 (Figura 17B) verifica-se que como a região atingida é oposta ao hilo, a distribuição do dano se estendeu em quase a totalidade dos cotilédones, atingindo a região vascular e parte do eixo embrionário na região da plúmula e hipocótilo, conseqüentemente comprometendo a viabilidade da semente.

Na Figura 17C é apresentada a semente 27, na qual o dano foi provocado na região da plúmula. Neste caso, o dano se distribui da plúmula até a parte inferior da semente, afetando todo o eixo embrionário e os cotilédones (semente não viável). Por outro lado, na Figura 17D (semente 16), pode ser observada a semente na qual o dano foi provocado na região oposta à plúmula, mostrando o efeito inverso ao da figura anterior (Figura 17C); o dano se estendeu desde o local do impacto até a plúmula, atingindo o eixo embrionário e comprometendo a viabilidade da semente. 
Na Figura 17E (semente 88) observa-se a semente com o dano provocado sobre 0 cotilédone esquerdo; 0 dano se estendeu pelo cotilédone, atingindo a região vascular (vigor baixo). Já na semente 46, 0 dano foi produzido sobre o cotilédone direito (Figura 17F), concentrandose a região do impacto no cotilédone, sem atingir o eixo embrionário (vigor médio).
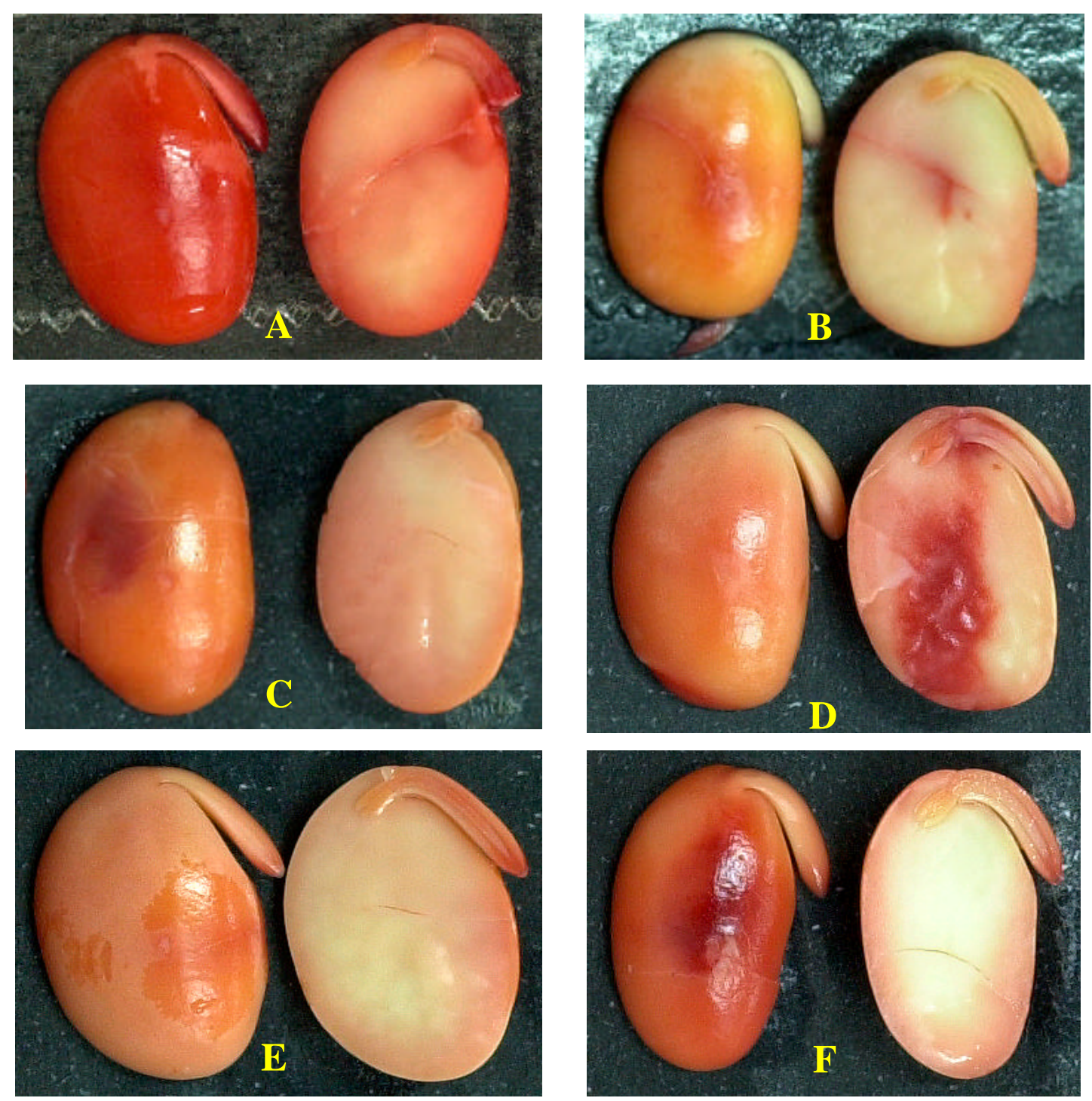

Figura 16 - Teste de tetrazólio: sementes do cultivar FT-2, submetidas ao teste do pêndulo nos diferentes locais onde os danos foram provocados: A: no hilo (semente 11); B: na parte oposta ao hilo (semente 25); C: na plúmula (semente 56); D: na parte oposta à plúmula (semente 42); E: sobre 0 cotilédone esquerdo (semente 67); F: sobre 0 cotilédone direito (semente 31) 

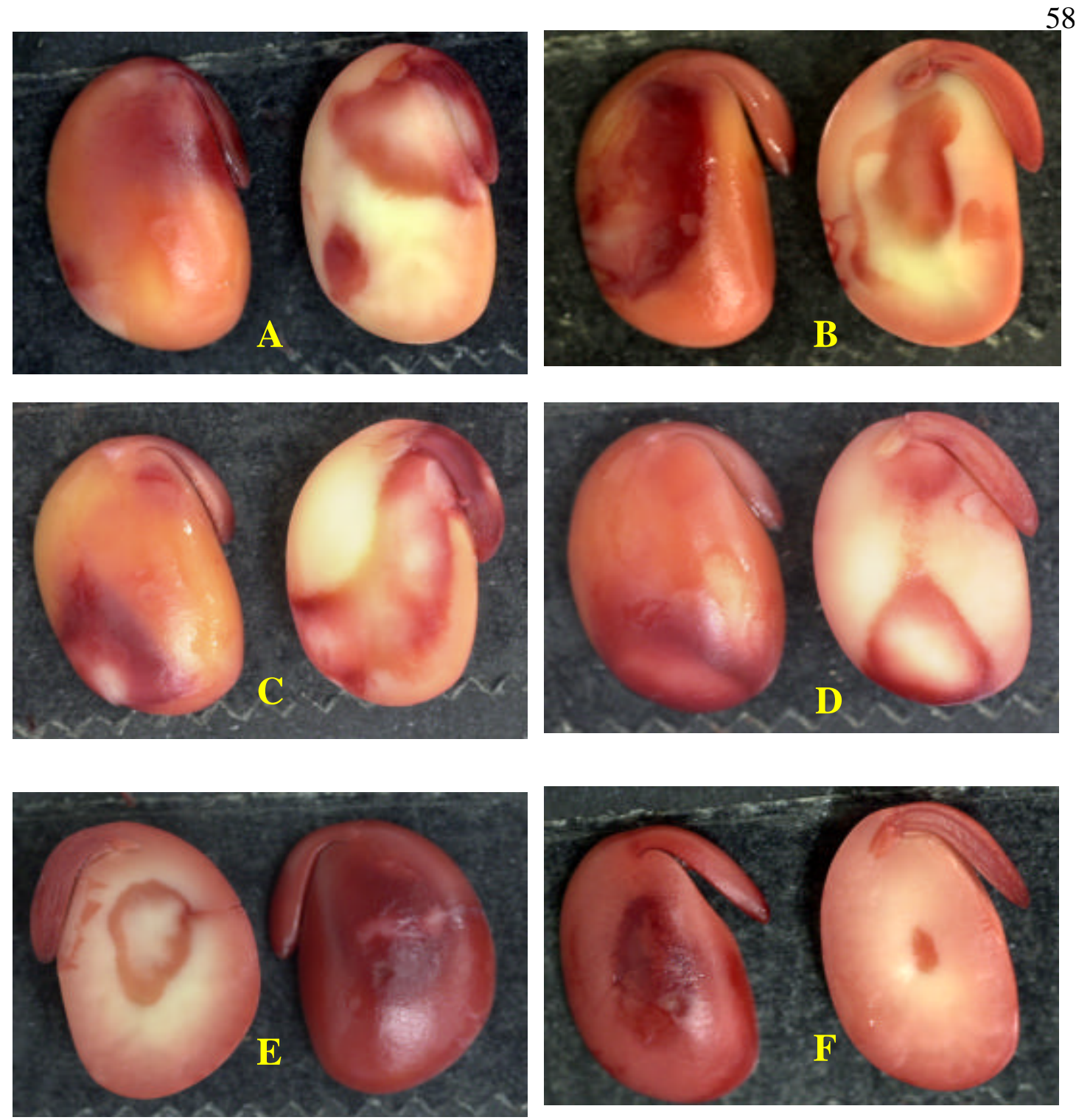

Figura 17 - Teste de tetrazólio: sementes do cultivar FT-10, submetidas ao teste do pêndulo nos diferentes locais onde os danos foram provocados: A: no hilo (semente 38); B: na parte oposta ao hilo (semente 12); C: na plúmula (semente 27); D: na parte oposta à plúmula (semente 16); E: sobre 0 cotilédone esquerdo (semente 88); F: sobre o cotilédone direito (semente 46) 
Na Figura 18, observam-se as sementes do cultivar IAC-2, com os diferentes tipos de danos provocados pelo teste do pêndulo e avaliados pelo teste de tetrazólio.

Na Figura 18A, podese observar a semente 13, a qual teve dano provocado na região do hilo; 0 impacto provocou o rompimento dos tecidos e, por conseguinte, o quebramento de um dos cotilédones e parte do eixo embrionário (hipocótilo e radícula), tornando a semente inviável.

Na Figura 18B pode-se observar a semente 75, que sofreu o dano na região oposta ao hilo, mostrando danos severos em quase a totalidade da semente, podendo-se observar que o impacto se distribui em quase toda a semente, chegando inclusive a produzir uma fratura no eixo embrionário, inviabilizando a germinação (semente não viável).

Na semente 30, Figura 18C, pode-se observar a semente com o dano provocado na plúmula, com um dos cotilédones e parte do eixo embrionário seccionados; no outro cotilédone o dano é visível na plúmula e se distribui até a parte inferior da semente, resultando em uma semente não viável.

Na Figura 18D, semente 14, na qual o dano foi provocado na parte oposta à plúmula, pode-se observar que o efeito do impacto estendeu-se através de todo o cotilédone, chegando até a região da plúmula e hipocótilo, seccionando o eixo embrionário, sendo uma semente não viável.

Na Figura 18E, observa-se a semente 62, com o dano provocado sobre 0 cotilédone esquerdo. 0 impacto produzido pelo teste do pêndulo proporcionou um amassamento externo e uma fratura severa do cotilédone, tornando a semente inviável.

A semente 72 da Figura 18F, mostra a semente com o dano que foi provocado sobre 0 cotilédone direito, onde observa-se 0 amassamento da 
parte externa do cotilédone e, também, a fratura interna, resultando em uma semente de baixo vigor.
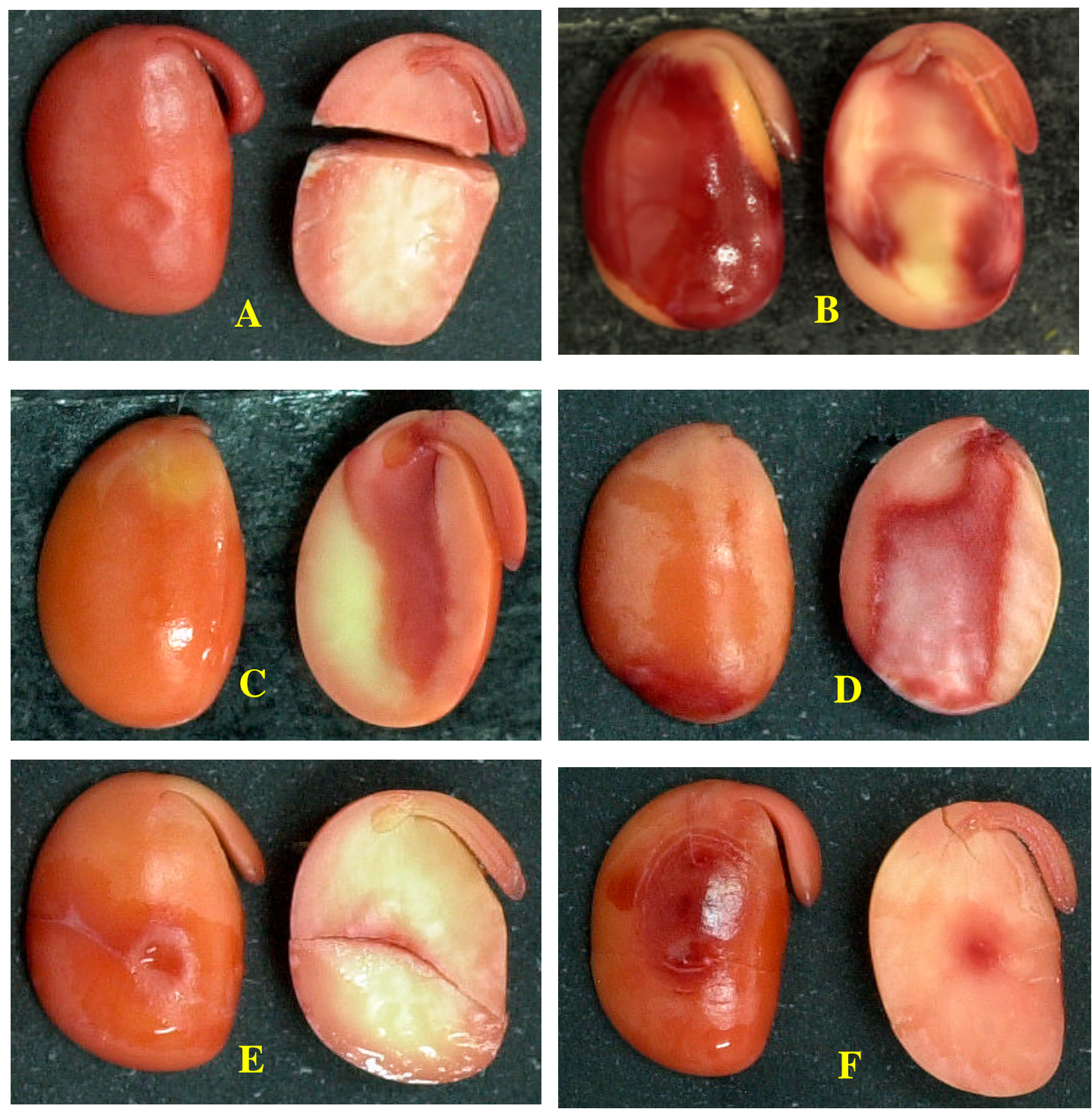

Figura 18 - Teste de tetrazólio: sementes do cultivar IAC-2, submetidas ao teste do pêndulo nos diferentes locais onde os danos foram provocados: A: no hilo (semente 13); B: na parte oposta ao hilo (semente 75); C: na plúmula (semente 30); D: na parte oposta à plúmula (semente 14); E: sobre 0 cotilédone esquerdo (semente 62); F: sobre o cotilédone direito (semente 72) 
De maneira geral, o teste de tetrazólio comprovou que há diferenças entre cultivares quanto à resistência ao dano mecânico, sendo que o cultivar IAC-2 apresentou danos mais severos e, em conseqüência, menor resistência ao dano mecânico quando comparado com os cultivares FT-10 e FT-2. Alvarez (1994) separou as sementes dos cultivares FT-2, FT-10 e IAC-2, de acordo com o teor de lignina presente no tegumento, conferindo-lhes diferentes comportamentos quanto à resistência aos danos mecânicos, sendo que o cultivar FT-2 possuía 6,19\% de lignina (maior resistência), FT-10 com 5,28\% (medianamente resistente) e IAC-2 com 4,21\% (menor resistência).

Da mesma forma, quando se analisa o impacto sobre a região de dano, o cultivar IAC-2 se mostrou mais suscetível. Q uando são observadas as regiões de dano para os três cultivares, observa-se que a região do hilo e na região da plúmula, foram as que mais afetaram a qualidade das sementes, pois as mesmas receberam o impacto do pêndulo de maneira direta. Vale ressaltar que a conseqüência do impacto mecânico sobre as sementes de soja, varia de acordo com a posição de ocorrência do dano. De acordo com Barstch et al. (1986) as regiões do eixo embrionário e oposta ao hilo, foram as regiões que mais influenciaram para a queda do vigor das sementes.

D entre os testes utilizados para detectar danos mecânicos, o teste de tetrazólio tem se destacado, principalmente para soja, devido a sua rapidez e precisão. Este é capaz de identificar três tipos de danos mecânicos: rachaduras, amassamentos e abrasões (Krzyzanowski et al., 1999). Entretanto, este é um teste que promove a destruição das sementes analisadas, impossibilitando assim, um diagnóstico preciso da real conseqüência do dano na qualidade das sementes. 


\subsection{Considerações Gerais}

O teste do pêndulo se mostrou como um método muito drástico na danificação das sementes dos três cultivares, sendo que tal fato pode ser observado quando se comparam as porcentagens de plântulas normais da testemunha com as dos demais tratamentos (Tabela 8).

Através da análise de imagens (externa e interna), de maneira geral, observou-se que houve diferenças entre as notas atribuídas às sementes, relativas às intensidades de danos mecânicos dos três cultivares, sendo que 0 cultivar menos suscetível ao dano mecânico (FT-2), apresentou menores índices de danos severos (nota 3) e índices mais altos de sementes sem danos externos (nota 1).

Os danos provocados sobre os cotilédones esquerdo e direito proporcionaram menores porcentagens de danos severos, possibilitando, desta maneira, maiores porcentagens de plântulas normais. Esse comportamento pode ser explicado pelo fato dos danos provocados nos referidos locais não terem apresentado uma dispersão acentuada do dano na semente. Por outro lado as regiões do hilo, a região oposta ao hilo, a plúmula e oposta à plúmula proporcionaram menores porcentagens de plântulas normais.

A análise feita por meio do teste de tetrazólio para avaliar a viabilidade e 0 vigor, também indicou que os três cultivares foram afetados pelos danos mecânicos, sendo que a queda mais drástica na qualidade das sementes foi verificada quando o dano mecânico foi provocado na região do hilo, na região oposta ao hilo, na plúmula e na região oposta à plúmula. Por outro 
lado, efeitos menos prejudiciais foram obtidos quando 0 dano foi provocado sobre os cotilédones esquerdo e direito. O cultivar FT-2 apresentou, em geral, melhor nível de viabilidade e de vigor do que os cultivares FT-10 e IAC-2, depois de terem sido submetidos ao teste do pêndulo. Para o cultivar IAC-2 a redução da viabilidade e do vigor foram mais acentuadas, destacando-se nesta comparação a maior resistência do cultivar FT-2 ao dano mecânico em relação ao cultivar IAC-2, que apresentam, respectivamente, alto e baixo percentuais de lignina no tegumento de suas sementes.

Para melhor comparação entre os métodos utilizados, foram realizadas análises de correlação entre a análise de imagens e 0 teste do tetrazólio para avaliar a viabilidade e os danos mecânicos (Tabela 13). Os resultados mostram que nos dois casos (viabilidade e danos mecânicos), existem correlações positivas para os três cultivares; assim, à medida em que aumentam, proporcionalmente, os valores de viabilidade e danos mecânicos obtidos pela análise de imagens, aumentam também na análise realizada pelo teste do tetrazólio. Estes resultados indicam que a análise de imagens surge como mais uma ferramenta para avaliar a viabilidade e os danos mecânicos em sementes (da mesma forma que o teste de tetrazólio), podendo ser incluída nos programas de controle de qualidade das empresas produtoras de sementes de soja.

Tabela 13. Valores de correlação entre a análise de imagens e o teste do tetrazólio na avaliação da viabilidade de danos mecânicos em sementes dos três cultivares estudados

\begin{tabular}{cccc}
\hline & \multicolumn{3}{c}{ Cultivar } \\
\cline { 2 - 4 } & FT-2 & FT-10 & IAC-2 \\
\hline Viabilidade & 0,717087 & 0,749733 & 0,682747 \\
Dano Mecânico & 0,795175 & 0,768213 & 0,710187 \\
\hline
\end{tabular}




\section{CONCLUSÕES}

- O s resultados obtidos indicam que a análise de imagens permite identificar danos mecânicos externos e internos em sementes de soja; também, permite observar danos por umidade e danos por percevejo.

- A análise de imagens correlaciona-se positivamente com o teste de tetrazólio, nas avaliações de danos mecânicos e de viabilidade das sementes. 


\section{REFERÊNCIAS BIBLIOGRÁFICAS}

AGRAWAL, P.K..; MENON, S.K. Lignin content and seed coat thickness in relation to seed coat cracking in soybean. Seed Research, v.2, p.64-66, 1974.

ALVAREZ, P.J. Relação entre o conteúdo de lignina no tegumento de semente de soja e sua relação ao dano mecânico. Londrina, 1994. 43p. Dissertação (Mestrado) - Universidade Estadual de Londrina.

ASSOCIATION OF OFFICIAL SEED ANALYSTS. Seed vigor testing. East Leasing, 1983. 88p. (Handbook. Contribution, 32).

BARTSCH, J.A.; HAUG H, C.G.; ATHOW, K.L.; PEART, R.M. Impact damage to soybean seed. Transactions of the ASAE, v.29, n.2, p.582586, 1986.

BATTISTI, A; CANTINI, R.; FECI, E.; FRIGIMELICA, G.; GUIDO , M.; ROQUES, A. Detection and evaluation of seed damage of cypress, Cupresus samperirensL.; in Italy. Seed Science and Technology, v.28, n.3, p.729-738, 2000.

BINO, R. J.; AARTSE, J.W.; VAN DER BURG, W.J. Non-destructive X-ray analysis on Arabidqpsis embryo mutants. Seed Science Research, v.3, n.2, p.167-170, 1993. 
BRASIL. Ministério da Agricultura. Regras para análise de sementes. Brasília, 1992. 365p.

CARBO NELL, S.A.M. Metodologia para seleção de genótipos de soja com semente resistente ao dano mecânico. Londrina, 1991. 103p. Dissertação (Mestrado) - Universidade Estadual de Londrina.

CARBONELL, S.A.M.; KRZYZANOWSKI, F.C. The pendulum test for screening soybean genotypes for seeds resistant to mechanical damage. Seed Science and Technology, v.23, n.2, p.331-339, 1995.

CARBO NELL, S.A.M.; KRZYZA NOWSKI, F.C.; OLIVEIRA, M.C.N. de; FONSECA JUNIOR, N. da S. Teor de umidade das sementes de soja e métodos de avaliação ao dano mecânico provocado no teste do pêndulo. Pesquisa Agropecuánia Brasileira, v.28, n.11, p.1277-1285, 1993.

CARVALHO, M.L.M; OBAND O-FLOR, E.P.; CABRAL, P. Internal damages of drying, evaluated by X-ray test and its effects on the quality of stored corn seeds (Zea mays L.). In: INTERNATIONAL SEED TESTING CONGRESS-SEED SYMPOSIUM, 26., Angers, 2001. Abstracts. Angers: ISTA, 2001. p.73.

CARVALHO, M.L.M.; VAN AELST, A.C.; VAN ECK, J.W.; HOEKSTRA, F.A. Pre harvest stress cracks in maize (Z mays L) kernels as characterized by visual, $\mathrm{X}$-ray and low temperature scanning electron 
microscopical analysis: effect on kernel quality. Seed Science Research, v.9, n.3, p.227-236, 1999.

CHAVAGNAT, A.; LE LEZEC, M. Assessment of seed quality by industrial X-ray radiography. Application to apple seeds (Malus pumila Mill.). Agronomie, v.5, p.187-192, 1984.

CÍCERO, S. M.; VAN DER HEIJDEN, G.W.A.M., VAN DER BURG W.J., BINO, R.J. Evaluation of mechanical damages in seeds of maize (Zea maysL) by X ray and digital imaging. Seed Science and Technology. v.26, p.603-612, 1998.

COSTA, A.V.; KUENEMAN, E.A.; MONTEIRO, P.M.F.D. Varietal differences in soybean for resistance to physical damage of seed. Soybean Genetics Newsletter, v.14, p.73-76, 1987.

FRANÇA NETO, J.B.; HENNING , A.A. Qualidade fisiológica e sanitária de sementes de soja. Londrina: EMBRAPA, CNPSo, 1984. 39p. (EMBRAPA. CNPSo, Circular Técnica, 9).

FRANÇA NETO, J.B.; KRZYZANOWSKI, F.C.; COSTA, N.P. da. Metodologia do teste de tetrazólio em sementes de soja. In: KRZYZANOWSKI, F.C.; VIEIRA, R.D .; FRANÇA NETO, J.B. Vigor de sementes: conceitos e testes. Londrina: ABRATES, 1999. p.85. 
FRANÇA NETO, J.B.; WEST, S.H.; VAUGHAN, W.R. Multiple quality evaluation of soybean seed produced in Florida in 1986. Soil and Crop Science Society of Florida Proceedings, v.47, p.20-22, 1987.

FRANÇA NETO, J.B.; PEREIRA, L.A.G.; COSTA, N.P.; KRZYZANOWSKI, K.C.; HENNING, A.A. Metodologia do teste do tetrazólio em sementes de soja. Londrina: EMBRAPA, CNPSo, 1988. 60p. (EMBRAPA. CNPMSo. D ocumentos, 32).

GIRARDIN， P.; CHAVAGNAT， A. and BOCKSTALLER， C. Determination des charactéristiques des semences de mais grace a la radio graphie rayons $X$. (D etermination of characteristic of corn seed by X-ray). Seed Science and Technology, v.21, p.545-551, 1993.

INTERNATIONAL SEED TESTING ASSOCIATION. International rules for testing seed. Seed Science and Technology, v.13, n.2, p.300520, 1985.

INTERNATIONAL SEED TESTING ASSOCIATION. International rules for seed testing. Seed Science and Technology, v.21, (suppl.) 363p., 1993.

KAMRA, S.K. D etermination of germinability of melon with X-ray contrast method. Proceedings of the Intemational Seed Testing Association, v.31, n.5, p.719-729, 1966.

KRZYZANOWSKI, F.C.; VIEIRA, R.D.; FRANÇA NETO, Vigor de sementes: conceitos e testes. Londrina: ABRATE S, 1999. 218p. 
KRZYZANOWSKI, K.C.; COSTA, N.P.; MIRANDA, Z.F.S; KIIHL, R.A.S.; KASTER, M.; SO UZA, P.I. Caracterização de genótipos de soja de ciclos precoce e médio quanto à qualidade fisiológica e suas interrelações com aspectos morfológicos. In: EMBRAPA. Centro Nacional de Pesquisa de Soja. Resultados de pesquisa de Soja 1988/ 89. Londrina, 1989. p.315-324.

KUENEMAN, E.A. Breeding for resistance to physical damage to soybean seed. In: WORLD SOYBEAN RESEARCH CONFERENCE, 4., Buenos Aires, 1989. Actas. Rosario: Asociación Argentina de Soja, 1989. v.2, p.1086-1090.

LIU, Y.; VAN DER BURG, W. J.; AARTSE, J.W.; VAN ZWOL, R. A.; JALINK, H.; BINO, R. J. X-ray studies on changes in embryo and endosperm morphology during priming and imbibition of tomato seeds. Seed Science Research, n.3, p.171-178, 1997.

MACHAD O, C.F. Metodologia para a condução do teste de germinação e utilização de raios-X para a avaliação da qualidade de sementes de aroeira-branca (Lithraa molleidss (Vell.) Engl.). Piracicaba, 2002. 51p. Dissertação (Mestrado) - Escola Superior de Agricultura "Luiz de Queiroz", Universidade de São Paulo.

MARCOS FILHO, J. Teste de envelhecimento acelerado. In: KRZYZANOWSKI, F.C.; VIEIRA, R.D .; FRANÇA NETO, J.B. (Ed.). Vigor de sementes: conceitos e testes. Londrina: ABRATES, 1999. cap.3, p.1-24. 
MARCOS FILHO, J.; CÍCERO, S.M.; SILVA, W.R. da. Avaliação da qualidade das sementes. Piracicaba: FEALQ, 1987. 230p.

MATTHEWS, S.; POWELL, A.A. Electrical conductivity test. In: PERRY, D.A. (Ed.). Handbook of vigour test methods. Zurich: ISTA, 1981. p.37-42.

O BAND O-FLOR, E.P. D anos internos de secagem avaliados pelo teste de raios-X e seus efeitos na qualidade de sementes de milho (Z mays L.) armazenadas. Lavras, 2000. 63p. Dissertação (Mestrado) - Universidade Federal de Lavras.

O BAND O-FLOR, E.P.; CARVALHO , M.L.; COSTA, P.S.C. Utilização dos raios- $X$ na avaliação da qualidade fisiológica em sementes de melão (Cuamis mid). In: CONGRESSO BRASILEIRO DE SEMENTES, 12., Curitiba, 2001. Anais. Londrina: ABRATES, 2001. p.57.

O LIVEIRA, L.M. de. Avaliação da qualidade de sementes de canafístula (PAttophonm dubium (Sprengel) Taubert) pelos testes de germinação, tetrazólio e raios-X. Lavras, 2000. 111p. Dissertação (Mestrado) Universidade Federal de Lavras.

PAULSEN, M.R. Fracture resistance of soybean to compressive loading. Transactions of the ASAE, v.21, n.6, p.1210-1216, 1978.

PAULSEN, M.R.; NAVE, W.R.; GRAY, L.E. Soybean seed quality as affected by impact damage. Transactions of the ASAE, v.24, p.15771582,1589, 1981. 
PO PINIGIS, F. Immediate effects of mechanical injury on soybean (Glydie nax (L.) Merr.) seed. Starkville, 1972. 72p. Thesis (Ph. D) - Mississippi State University.

PO PINIG IS, F. Fisiologia de semente. Brasília: AG IPLAN, 1985. 289p.

POULSEN, K.M.; PARRATT, M.J.; GOSLING, P.G. (Ed.) Tropical and subtropical tree and shrub seed handbook. Zurich: International Seed Testing Association, 1998. 204p.

PUKitTAYACAMEE, P.; HELlUM, A.K. Seed germination in Acada aunalifomis developmental aspects. Canadian Joumal of Botany, v.66, n.2, p.388-393, 1988.

SAHLÉN, K.; BERGSTEN, U.; WIKLUND, K. Determination of viable and dead scots pine seeds of different anatomical maturity after freezing using the IDX method. Seed Science and Technology, v.23, n.2, p.405414, 1995.

SIMAK, M.; GUSTAFSSO N, A. X-ray photography and sensitivity in forest tree species. Hereditas, v.39. p. 458-468, 1953.

SIMAK, M. X-radiography in research and testing of forest tree seeds. Umeå Swedish University of Agriculture Science: Department of Silviculture, 1980. 34p. (Report, 3).

SIMAK, M. A method for removal of filled-dead seeds from a sample of Pinus contata. Seed Science and Technology, v.12, n.3, p.767-775, 1984. 
SMITH, A.J.; GRABE, D.F. Radiographic density measurements for determination of viability and vigour in corn (Zea mas) seeds. Seed Science and Technology, v.13, n.3, p.759-768, 1985.

STANWAY, V.M. Evaluation of "Forrest" soybean with damaged seed coat and cotyledons. Joumal of Seed Technology, v.3, n.1, p. 19-26, 1978.

SWAMINATHAN, M.S.; KAMRA, S.K. X-Ray analysis of the anatomy and viability of seeds some economic plants. Indian Joumal of Genetics $\boldsymbol{\&}$ Plant Breeding, v.21, n.2, p.129-135, 1961.

VAN DER BURG, W. J.; AARTSE, J. W.; VAN ZWOL, R. A.; JALINK, H.; BINO, F. J. Predicting tomato seedling morphology by X-ray analysis of seeds. Joumal of Amenican Society for Horticultural Science, v.119, n.2, p.258-263, 1994.

VIEIRA, R.D .; KRZYZANOWSKI, F.C. Teste de condutividade elétrica. In: KRZYZANOWSKI, F.C.; VIEIRA, R.D.; FRANÇA NETO, J.B. (Ed.). Vigor de sementes: conceitos e testes. Londrina: ABRATES, 1999. cap.4, p.1-26.

ZONTA, E.P.; MACHADO, A.A. Sistema de análise estatística para microcomputadores - SANEST. Pelotas: UFPel, 1984. (Registro SEI nํㅜ 06606-0, Categoria AO). 